AperTO - Archivio Istituzionale Open Access dell'Università di Torino

\title{
Biochronology and palaeoenvironmental changes from the Middle Pliocene to the Late Pleistocene in Central Italy.
}

This is the author's manuscript

Original Citation:

Availability:

This version is available http://hdl.handle.net/2318/128607

since

Published version:

DOI:10.5252/g2011n3a4

Terms of use:

Open Access

Anyone can freely access the full text of works made available as "Open Access". Works made available under a Creative Commons license can be used according to the terms and conditions of said license. Use of all other works requires consent of the right holder (author or publisher) if not exempted from copyright protection by the applicable law. 


\title{
Biochronology and palaeoenvironmental changes from the Middle Pliocene to the Late Pleistocene in Central Italy
}

\author{
Carmelo PETRONIO \\ Luca BELLUCCI \\ Dipartimento di Scienze della Terra, "Sapienza", Università di Roma, \\ Piazzale A. Moro, 5, IT-00185 Roma (Italy) \\ carmelo.petronio@uniroma1.it \\ Ibellucci78@gmail.com \\ Edoardo MARTIINETTO \\ Dipartimento di Scienze della Terra, Università di Torino, \\ via Valperga Caluso, 35, IT-10125 Torino (Italy) \\ edoardo.martinetto@unito.it \\ LUCa PANDOLFI \\ Leonardo SALARI \\ Dipartimento di Scienze della Terra, "Sapienza", Università di Roma, \\ Piazzale A. Moro, 5, IT-00185 Roma (Italy) \\ leonardosalari@virgilio.it \\ I.pandolfi@yahoo.it
}

Petronio C., Bellucci L., Martiinetto E., Pandolfi L. \& Salari L. 2011. - Biochronology and palaeoenvironmental changes from the Middle Pliocene to the Late Pleistocene in Central Italy. Geodiversitas 33 (3): 485-517. DOI: 10.5252/g2011n3a4.

\begin{abstract}
Paleoenvironmental variations that occurred in Italy from the Middle Pliocene to the Late Pleistocene are described. The number of large mammal species seems increased moderately, especially from the Galerian to the Late Aurelian biochronological units. On the contrary, the paleobotanical data show a decrease of the forest cover from the Middle Pliocene to the late Early Pleistocene and an increase of lands occupied by prairies and steppes. This change is also supported by the appearance of hypsodont taxa among mammals. The distribution of mammal faunas between the Adriatic and Tyrrhenian sides of Central Italy, during the Middle and Late Pleistocene, seems not to be influenced by climatic and environment differences. When the Adriatic data are more complete, it is possible, in fact, to observe a trend that is fairly close to that of the Tyrrhenian. The majority of megaherbivorous taxa has an Asian origin, and it can be hypothesized that in the interglacial phases, the Tosco-Emilian Apennines allowed the taxa coming from the northeast to enter and spread out into the more diversified Tyrrhenian side, whereas during the glacial periods the
\end{abstract}


KEY WORDS

Biochronology,

Italy,

Pliocene,

Pleistocene,

large mammals.
MOTS CLÉS

Biochronologie, Italie,

Pliocène,

Pléistocène, grands mammifères. narrow Ligurian corridor were followed. This research supports the role of the Italian Peninsula as a refuge area for continental Europe; this particular condition permits the Italian mammal faunas to develop endemic lineage (such as Elephas antiquus italicus Osborn, 1931, Cervus elaphus rianensis Leonardi \& Petronio, 1974, C. e. aretinus Azzaroli, 1947, etc.). At last, biodiversity sharply dropped during the last 30000 years, probably due to the anthropic activities and the strong climatic cooling of the last pleniglacial.

\section{RÉSUMÉ}

Biochronologie et variations paléo-environnementales en Italie centrale du Pliocène moyen à la fin du Pléistocène.

Les variations paléo-environnementales qui ont eu lieu en Italie du Pliocène moyen au Pléistocène supérieur sont décrites. Il semblerait que le nombre des espèces de mammifères de grande taille ait peu augmenté, surtout pour les unités biochronologiques du Galérien à l'Aurélien supérieur. Au contraire, les données paléobotaniques montrent une diminution progressive des espèces arborées depuis le Pliocène moyen jusqu'au début du Pléistocène inférieur et une augmentation des surfaces occupées par les prairies et les steppes. Ces derniers évènements sont attestés par l'apparition des espèces hypsodontes parmi les mammifères. La répartition des faunes de mammiferes entre les côtes adriatique et tyrrhénienne de l'Italie centrale, pendant le Pléistocène moyen et supérieur, semble ne pas avoir été influencée par des différences climatiques et environnementales. Quand les données sur l'Adriatique sont plus complètes, il est en fait alors possible d'observer une tendance qui est similaire à celles de la Tyrrhénienne. La plupart des mégaherbivores ont une origine asiatique, et on peut émettre l'hypothèse que dans les phases interglaciaires, l'Appennin toscan-émilien a permis aux taxons qui venaient du Nord-Est de l'Europe, de rentrer et se diffuser sur la côte de la mer Tyrrhénienne, plus diversifiée, alors que durant les périodes glacières, ils ont suivi l'étroit couloir de la Ligurie. Cette recherche confirme encore le rôle de la péninsule italienne comme aire de refuge de l'Europe continentale; cette condition particulière a permis aux faunes de mammiferres italiennes de développer des lignées endémiques (comme Elephas antiquus italicus Osborn, 1931, Cervus elaphus rianensis Leonardi \& Petronio, 1974, C. e. aretinus Azzaroli, 1947, etc.). Pour terminer, la biodiversité a subi une forte chute dans les derniers 30000 ans, très probablement provoquée par les activités anthropiques et le refroidissement climatique du dernier périglaciaire.

\section{INTRODUCTION}

Large mammal diffusion in Italian peninsula since Middle Pliocene to Late Pleistocene are conditioned mainly by the climatic fluctuations, that noticeably changed the ecological niches. These fluctuations seem to have developed a particular role, especially in the second part of the Pleistocene.
Trophic networks changed during this period because of a reduction of vegetation and/or by a gradual formation of different types of vegetation; and even the ecosystems were conditioned by the quantity and the quality of the migration of herbivorous macromammals that are pushed towards the southern regions because of different climatic events. The progressive climatic change 
in the Late Pliocene and the Pleistocene towards temporal intervals with lower mean temperatures, which caused forests and woods to thin out and be replaced by open habitats, allowed herbivorous mammals, among which pachyderms, to occupy the territory; these large mammals surviving even under unfavorable climatic conditions. Naturally, a gradual diffusion of cursorial hunters of different sizes successively followed the settlement herbivorous mammals. These carnivores (the ones following the herbivores and pachyderms) will gradually replace those from the Pliocene and the first part of the Pleistocene (Gliozzi et al. 1997; Petronio \& Sardella 1999; Petronio et al. 2007).

The paleobotanical data need to be considered within these global transformations over time. They demonstrate a noticeable latitudinal differentiation of the vegetation that had already begun in the Messinian (Favre et al. 2007). In this period open and steppic environments that had continued even through the Pliocene (Suc \& Bessais 1990; Suc et al. 1995a, b) already existed in southern Italy, while in continental Europe thick forests were present with a temperate climate; one similar to present-day Southern China (Favre et al. 2007; Martinetto 1996, 1999). This type of Mio-Pliocene forest extended into much of Central Europe, until Moldavia (Mai 1995), if not all the way into Georgia (Shakryl 1990), and in Italy it impeded and/or slowed down the penetration of prairie mammals that had already existed in Western Europe.

In addition to these climatic oscillations, some effects for the bioevents could have been occurred by the numerous paleomagnetic reversals that occurred in the Pliocene and in the Pleistocene (Sardella et al. 1998). According to geophysicists, every one of these reversals takes about 5000 years to complete (Merril et al. 1996). This distresses the biological compass of the animals migrating from Asia or Africa in search of new territories.

According to Gliozzi et al. (1997) these faunal changes are grouped in the Mammal Ages and in the Faunal Units. This allows a better understanding of how the dispersal events are connected to environmental and floristic conditions in a highly diversified territory like Italian peninsula.
The floristic characteristics and vegetation changes referable to each Faunal Unit have been reconstructed not only on the basis of the ecophysiological indications of the mammal species, but also on the basis of the flora fossil record (macro- and micropaleobotanical data).

As regards to the peninsula, considering that the Alps and the Po plain are part of continental Europe, the macromammal remains found in the central part of the peninsula, which also better represents the southern part of Europe, have been analyzed. Paleontological data from Puglia and in general from southern Italy have been disregarded since, beyond the relative scarcity of information, the remains of mammal fauna relative to sites in these regions often reveal particular aspects probably attributable to a moderate degree of endemism. The results of these analyses, relative to the fossil remains of Tuscany, Latium, Marche, Umbria, Abruzzo, and Molise have been compared with paleofaunal, biochronological, and paleoenvironmental data of all of the peninsula reviewed after Gliozzi et al. (1997).

The aims of this paper are therefore: the identification of the main faunal turnover in Italy; the possible discrepancies between these turnovers and those recorded in the central part of the Italian peninsula; the connection with the climatic variations and/or the Pleistocene changes in the environment - a possible correlation of the dispersal events with magnetostratigraphical changes; and, last, the relationship between several taxa and human activity, especially in the Late Pleistocene.

\section{PRELIMINARY REMARKS ON THE PLIO-PLEISTOCENE BIOCHRONOLOGY}

The biochronological study of the vertebrate faunas is based on the biostratigraphical concept of assemblage zone sequences (Gliozzi et al. 1997). Thus, the fossil remains of animals that presumably lived in the environments surrounding the depositional basin have been studied, observing also the paleoecological congruity and the evolutionary degree. This fossil assemblage defines a Local Fauna.

A particular Local Fauna wherein the greatest number of taxa is well represented and wherein one 
or more bioevents are pointed out for the first time (First Occurrences) is defined as a Faunal Unit. A few Faunal Units together, with a certain degree of ecological homogeneity, represents a Mammal Age; and this represents a large temporal interval, characterized by the occurrence of particular bioevents on a global scale (Gliozzi et al. 1997).

The Local Faunas, the Faunal Units and the Mammal Ages are integrated and correlated, when possible, with radiometric dating, magnetostratigraphical data, and oxygen (marine) isotopic stages (OIS/MIS). These data make it possible to define the temporal interval with sufficient approximation and then to arrange the numerous faunal sequences.

Since the data concerning these faunal assemblages is dependent on the fossil remains known up until today, it is evident that the temporal intervals between one Faunal Unit to the next are destined to vary, and at most, become more and more narrower; precisely because the recognition of either the taxa's initial appearance (F.O.) or the final appearance (L.O.) changes. Inasmuch as it is understandable that the Faunal Units are based on the presence and the migration of mammals in a regional area, most of the biochronological data that concern a specific territory can be difficult to extrapolate in a different region. This methodology, therefore, can only have a good regional utility. To correlate the dispersal events data in Italy with other European regions, references will need to be made to the radiometric chronology and to the relationships with the chronostratigraphy of the marine sediments (e.g., Early, Middle and Late Pleistocene). This feature obviously does not nullify the use of the Faunal Units, which in the field of a determined area can be considered a valid instrument to define the sequences of biochronological bioevents.

Between approximately 3.3 to $0.01 \mathrm{Ma}$ (Middle Pliocene-Holocene), wherein the modern faunas were formed, three Mammal Ages have been defined (Gliozzi et al. 1997; Petronio et al. 2007):

1. Villafranchian: from -3.3 to $-1.1 \mathrm{Ma}$ (Middle Pliocene and part of the Early Pleistocene);

2. Galerian: from $\sim 1.1$ to $-0.35 \mathrm{Ma}$ (part of the Early Pleistocene-late Middle Pleistocene);

3. Aurelian: from $\sim 0.35$ to $\sim 0.01 \mathrm{Ma}$ (late Middle Pleistocene-Late Pleistocene).
In regards to these Mammal Ages some temporal ranges of Faunal Units have been revised, the taxonomy of different species have been updated, and a few Faunal Units have recently been created (Petronio et al. 2007). These variations are reported in Figure 1 and in the text that follows.

\section{The Villafranchian Mammal Age}

The Villafranchian has recently been subdivided into early, middle and late (Gliozzi et al. 1997) with eight Faunal Units (F.U.):

- Early ( -3.3 to $2.6 \mathrm{Ma})$ : Triversa, Montopoli;

- Middle ( 2.6 to $1.8 \mathrm{Ma})$ : Saint Vallier, Costa San Giacomo;

- Late ( 1.8 to 1.1 Ma): Olivola. Tasso, Farneta, Pirro.

A renewal of the fauna is documented in Italy at the beginning of the Villafranchian, with a clear transition from the Ruscinian and archaic faunas, typical of temperate-warm environments, to faunas with more modern characteristics, indicative to less humid environments under cooler climates.

The age of the first F.U., Triversa, on the basis of paleomagnetic data, has been determined to be around $3.3 \mathrm{Ma}$ (Lindsay et al. 1980). The faunas are characterized by the occurence of new species and by the diffusion of animals also adapted to open habitats: among the carnivores, Chasmaporthetes lunensis Del Campana, 1914, Acinonyx pardinensis (Croizet \& Jobert, 1828), Homotherium crenatidens (Weithofer, 1889) and a small bear of modern form, Ursus minimus Devèze \& Bouillet, 1827 can be considered; amongst the herbivores, Axis lyra (Azzaroli, 1992) replaces the small Ruscinian cervids, Leptobos stenometopon (Rutimeyer, 1867), which replaced the Ruscinian antelopes, Stephanorhinus jeanvireti (Guérin, 1972) and Mammut (Zygolophodon) borsoni (Hays, 1834). Aside these new species, persisting from the Ruscinian, are Anancus arvernensis (Croizet \& Jobert, 1828), Tapirus arvernensis (Croizet \& Jobert, 1828), Macaca sylvanus (Linnaeus, 1758) and Sus minor (Depéret, 1890). In addition, the paleobotanical data indicate a considerable homogeneity of the vegetation, at least in Northern Italy, to the passage from the Ruscinian to the early Villafranchian; therefore, the survival of the animals strictly reliant on the 
forests is not surprising. Nevertheless, specifically in the sediments of the Val Triversa (Martinetto \& Mai 1996), like those of the coeval Fossil Forest of the Stura di Lanzo (Martinetto et al. 2007), floral elements that clearly indicate the predominance of willow trees in the mesofil forests have been identified, to the detriment of evergreen species that before 3.2 Ma were more abundant, if not predominant (Martinetto 1999).

An important faunal renewal, likely related to global climate cooling at about 2.7-2.5 Ma (MIS 104-100) occurred. This event coincides with an irreversible transformation of the climate regime that determines rapid variations of the vegetation community, according to a repetitive succession of vegetation types (Leroy 2007). The entire interval between 2.5 and $1.0 \mathrm{Ma}$ is characterized by relatively long interglacial periods, with rather thick forestal covering, and short glacial periods, with open vegetation or partly arboreal vegetation in Central and Southern Italy.

On the contrary, in Northern Italy, even the glacial periods were characterized by extensive forestal coverings; predominately microtherm conifers like Picea Link (Ravazzi 2002; Monegatti et al. 2002). By using the macropaleobotanical data (Mai 1994; Cavallo \& Martinetto 2001) it is possible to point out that these conifers did not belong to the current boreo-alpine lineage, but instead to a family of Asiatic origin: Picea florschuetzii Van der Hammen.

The disappearance of Tapirus Brisson, 1762 and Mammut Blumenbach, 1799, and the appearance of Equus livenzovensis Bajgusheva, 1978 and Mammuthus gromovi (Alexeeva \& Garutt, 1965) signal the passage to the Montopoli F.U., corresponding with the Gauss-Matuyama transition (Lindsay et al. 1980; Sardella et al. 1998). An abrupt reduction of the forests in favor of taxa adapted to open lands and arid climates, characterizes the transition between the two F.U.'s, defined the Equus-Elephant event (Azzaroli 1977). These taxa came from the East or from the Central-European regions. Even the giant Cervidae Gray, 1821, Eucladoceros falconeri Dawkins, 1868, appeared along with Croizetoceros ramosus (Croizet \& Jobert, 1828), Gazella borbonica Depéret, 1884 and Stephanorhinus etruscus (Falconer, 1868). Amongst the Carnivores, Lynx issiodorensis
(Croizet \& Jobert, 1828), Megantereon cultridens (Cuvier, 1824) and Pliocrocuta perrieri (Croizet \& Jobert, 1828) are present.

The paleobotanical data that better illustrate the progressive opening of the vegetation during the cold phases from MIS 108 to MIS 98 are provided by the Garraf 1 (Catalonia, Spain) (Suc $\&$ Popescu 2005). The Italian sites, on the other hand, do not provide precise indications on this opening of the vegetation, probably because continuous sections in the Tyrrhenian zone are missing. These sections cover the crucial, initial interval of when the fauna of Montopoli began. Evidence of steppic, open vegetation has been found in the Rena Bianca succession of the Upper Valdarno (Bertini 2006). This vegetation is characterized by the abundance of Artemisia L. In the Pliocene succession of San Miniato-Montopoli, from which the mammal fauna comes, the palynological analyses of Bertini (in Benvenuti et al. 2007) has shown evidence of the passage from warm-temperate forests to cooler ones. These cooler forests are characterized by the prevalence of conifers like Picea, recorded in strata older than that bearing the Montopoli mammal fauna (and for which paleobotanical data are lacking).

The middle Villafranchian is represented mainly in French deposits (in particular Saint Vallier, see for example Guérin et al. 2004). In this phase Equus stenonis Cocchi, 1867 appears, replacing the large E. livenzovensis and Mammuthus meridionalis (Nesti, 1824). The latter can be considered as the first, advanced mammoth that lived in open habitats.

Coste San Giacomo F.U. is a slightly more recent unit of Late Pliocene. In Italian peninsula the faunal changes continue with the evolution of proboscideans, perissodactyls and cervids (Eucladoceros tegulensis (Dubois, 1904)) and with the arrival of Leptobos ex gr. merlai De Giulii, 1987 -furtivus Duvernois \& Guérin, 1988, Gazellospira torticornis (Aymard, 1854), Sus strozzii Forsyth Major, 1881 and of the carnivore Canis ex gr. C. etruscus Forsyth Major, 1877.

Paleobotanical data directly associated with mammal faunas are missing from both of the Villafranchian F.U.'s. Nevertheless, the long pollen diagram of Pontini \& Bertini (2000) provides extremely important information on the variation of 


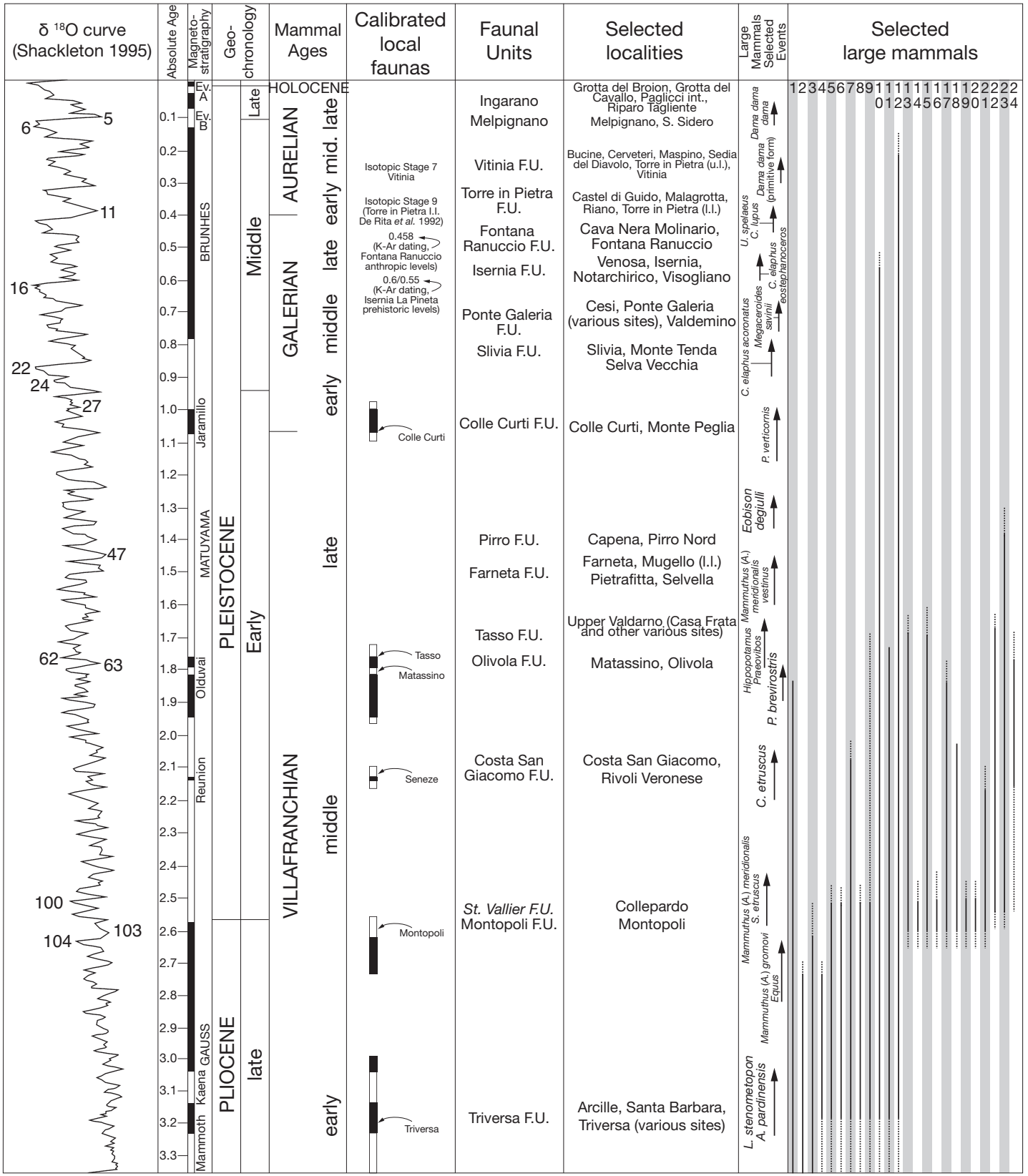

FIG. 1. - Distribution, first occurrences and last occurrences of the main macromammals on the Italian peninsula. Selected large mammals numbers: 1, Anancus arvernensis; 2, Tapirus arvernensis; 3, Sus minor; 4, Mammut borsoni; 5, Stephanorhinus jeanvireti; 6. Leptobos stenometopon; 7, Axis lyra; 8, Ursus minimus; 9, Acinonyx pardinensis; 10, Homotherium latidens; 11, Chasmaportetes lunensis; 12, Lynx ex gr. issiodorensis; 13, Megantereon cultridens; 14, Mammuthus gromovi; 15, Stephanorhinus etruscus; 16. Equus livenzovensis; 17, Gazella borbonica; 18, Nyctereutes megamastoides; 19, Croizetoceros ramosus; 20, Eucladoceros falconeri; 21, Pliocrocuta perrieri; 22, Mammuthus meridionalis meridionalis; 23, Equus stenonis; 24, Leptobos merlai-furtivus; 25, Macaca sylvanus; 26, Gazellospira torticornis; 27, Gallogoral meneghinii; 28, Canis etruscus; 29, Sus strozzii; 30, Vulpes alo- 


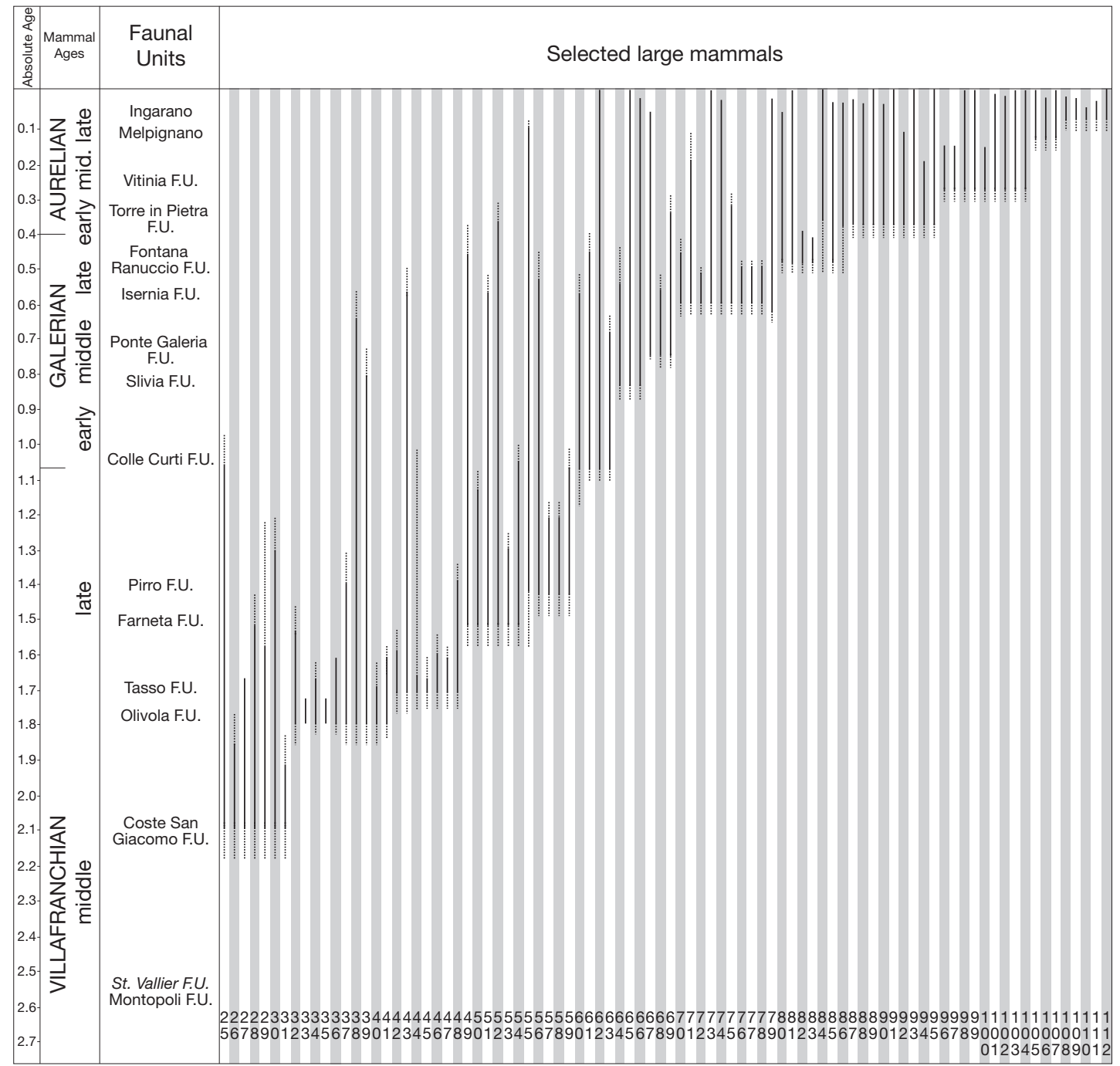

pecoides; 31, Eucladoreros tegulensis; 32, Leptobos etruscus; 33, Procamptoceras brivatense; 34, Eucladoceros dicranios; $\mathbf{3 5}$, Enhydrictis ardea; 36, Axis nestii; 37, Ursus etruscus; 38, Panthera gombaszoegensis; 39, Pachycrocuta brevirostris; 40, Felis lunensis; 41. Canis arnensis; 42, Equus stehlini; 43, Hippopotamus antiquus; 44, Leptobos vallisarni; 45, Eucladoceros ctenoides; 46, Lycaon falconeri; 47, Pannonictis nestii; 48, Hystrix refossa; 49, Axis eurygonos; 50, Mammuthus meridionalis vestinus; 51, Stephanorhinus hundsheimensis; 52, Equus ex gr. bress.-sussenbornensis; 53, Praemegaceros obscurus; 54, Megantereon whitei; 55, Canis mosbachensis; 56, Equus altidens; 57, Bison degiulii; 58, Theropthecus sp.; 59, Lycaon lycaonides; 60, Bison schoetensacki; 61, Ursus deningeri; 62, Sus scrofa; 63, Praemegaceros verticornis; 64, Cervus elaphus acoronatus; 65, Capreolus capreolus; 66, Crocuta crocuta; 67, Elephas antiquus; 68, "Bos" galerianus; 69, Mammuthus trogontherii; 70, Praemegaceros solihacus; 71, Stephanorhinus kirchbergensis; 72, Megaloceros savini; 73, Meles meles; 74, Equus ferus; 75, Dama clactoniana; 76, Panthera fossilis; 77, Hyaena prisca; 78, Hemitragus bonali; 79, Panthera pardus; $\mathbf{8 0 , ~ H i p p o p o t a m u s ~ a m p h i b i u s ; ~} \mathbf{8 1 , ~ B o s ~ p r i m i g e n i u s ; ~ 8 2 , ~ C e r v u s ~ e l a p h u s ~ e o s t e p h - ~}$ anoceros; 83, Cuon priscus; 84, Ursus arctos; 85, Stephanorinus hemitoechus; 86, Bison priscus; 87, Panthera spelaea; 88, Ursus spelaeus; 89, Canis lupus; 90, Megaloceros giganteus; 91, Vulpes vulpes; 92, Hystrix vinogradovi; 93, Mustela putorius; 94, Cervus elaphus rianensis; 95, Felis silvestris; 96, Mammuthus chosaricus; 97, Cervus elaphus aretinus; 98, Capra ibex; 99, Rupicapra rupicapra; 100, Dama dama tiberina; 101, Equus hydruntinus; 102, Gulo gulo; 103, Mustela nivalis; 104, Martes martes; 105, Cervus elaphus elaphus; 106, Dama dama dama; 107, Lynx lynx; 108, Cuon alpinus; 109, Mammuthus primigenius; 110, Marmota primigenia; 111, Coelodonta antiquitatis; 112, Mustela erminea. 
the vegetation in Central Italy during part of the Late Pliocene (middle Villafranchian). This diagram shows two long phases, in which the glacial intervals are characterized by open, steppe-type vegetation. During these alternate phases the forests seem to be present in the long interglacial periods and in the short glacial intervals. The sampling resolution of the mammal assemblages is still insufficient to discriminate between one specific type of vegetation to another. However, one can hypothesize that the aforementioned prairie animals, which reached Central Italy in the middle Villafranchian, had an advantage in open lands (generated in the "steppic" phases) and they could have even then caused an impact on the vegetation, preventing its closure when favorable climatic conditions came back.

The passage to the late Villafranchian faunas was achieved at the end of the Pliocene. The Olivola F.U. (its name deriving from the site of Val di Magra) corresponds to the upper part of the Olduvai subchron, dated at about 1.7 Ma. The fauna is characterized by the arrival of Canidae (Fischer de Waldheim, 1817) Gray, 1821, Canis arnensis Del Campana, 1913, similar to the jackal, and by Lycaon falconeri (Forsyth Major, 1877); thus confirming the reduction of the forests, together with the diffusion of species adapted to steppic or prairie areas, like the medium-large sized bovid Leptobos etruscus (Falconer, 1868), together with Equus stenonis and Mammuthus meridionalis. Forest environments are still present as confirmed by the first occurrence of the Eurasian jaguar (Panthera gombaszoegensis (Kretzoi, 1938)), a bear (Ursus etruscus Cuvier, 1823) and two new species of Cervidae (Eucladoceros dicranios (Nesti, 1841) and Axis nestii (Azzaroli, 1947)). Pliocrocuta perrieri, Anancus arvernensis and Gazella borbonica dissappeared.

Direct paleofloristic evidence is available for the sites of Torre Picchio and Villa San Faustino (Girotti et al. 2003), where a temperate-warm vegetation of willow forest and a mixed forest of conifer-willow (with a temperate-cold climate) has been documented. The presence of Picea macrofossils at low altitudes testifies the harshness of the climate even in Central Italy. The reduction of the forest, indicated by the mammals, is confirmed also by the already cited steppic phase, shown in the upper part of the pollen diagram of Pontini \& Bertini (2000) or in successive phases.

In regards to the F.U. immediately following (Tasso), a palynological study in the Poggio Rosso (Upper Valdarno) area has recently been conducted, which has pointed out forestal phases that are spaced-out by herbaceous phases, indicating open lands, precisely corresponding with a deposit rich in vertebrates (Mazza et al. 2004). Nonetheless, forest phases are well documented in the same area, even by macrofossils of trees with an Asiatic (Cephalotaxus Siebold \& Zuccarini, Pterocarya Kunth), American (Juglans bergomensis (BalsamoCrivelli)) or Asiatic-American (Liquidambar Linnaeus, Liriodendron Linnaeus) affinity (Martinetto 2001). In general, even the mammals of this F.U. seem to indicate the predominance of open lands that will be accentuated in the following F.U.'s, with the arrival of new species typical of steppe/ prairie environments.

The large-sized canid Lycaon falconeri appears. Moreover a medium-sized equid, Equus stehlini Azzaroli, 1965, adapted to running, and a leptobovine, with a morphology similar to a bison Leptobos vallisarni Merla, 1949 also occur. Other Bovidae of medium size, however, disappear. The genus Eucladoceros Falconer, 1868 is present with two new species: E. dicranios and E. ctenoides (Nesti, 1841).

In addition the large-sized hippopotamus (Hippopotamus antiquus Desmarest, 1822), much adapted to aquatic life, has been recorded at Monte Riccio (associated with a late Villafranchian fauna) (Mazzini et al. 2000). The Upper Valdarno specimen have to be referred, according to Napoleone et al. (2003), to a depositional cycle younger than that bearing the Tasso F.U. mammal assemblages (possibly to be referred to Farneta F.U.).

During the Early Pleistocene a more marked renewal of the faunas took place, with a progressive disappearance of the Villafranchian species and the gradual arrival of new species that will characterize the Middle Pleistocene. In the Farneta F.U., alongside the large Villafranchian Cervidae and Bovidae Gray, 1821 of the genus Leptobos Rütimeyer, 1877 and Eucladoceros comes a primitive form of giant megacerine deer (Praemegaceros 
obscurus (Azzaroli, 1953)); megacerine deers will dominate the assemblage in the Galerian, substituting the genus Eucladoceros. The evolution among the medium-sized Cervidae continues in loco with the genus Axis Gray, 1825: Axis nestii is substituted by a more advanced form (Axis eurygonos (Azzaroli, 1947)) with antlers and pedicle clearly shorter, and with the first beam in proximity to the rose with a more obtuse angle (Di Stefano \& Petronio 2002). Among the Perissodactyla, the equid Equus sussenbornensis Wüst, 1901 and a small-sized rhino, Stephanorhinus cf. hundsheimensis (Toula, 1902), are present. Mammuthus meridionalis is present with an advanced form referred, in the past century, to M. m. vestinus Azzaroli, 1977. Recent analyses of the Early Pleistocene elephantids from Italy suggest that this form could be considered not valid, and differences in the specimens due to intraspecific and ontogenetic variability (Palombo \& Ferretti 2005). From a paleobotanical point of view the aforementioned faunal renewal cannot easily be explained because the long pollen diagram available for the Pietrafitta site (Lona \& Bertoldi 1973) does not show evidence of drastic changes of the vegetational successions and of the cyclicity in respect to the preceding intervals.

In the successive Pirro F.U., the data indicate the prevalence of open lands. In fact a primitive bison, Bison degiulii (Masini, 1988), which indicates more rigid and arid conditions that are not fit for the leptobovine, and a light built, medium-sized Equidae, Equus altidens Reichenau, 1915, occur for the first time. The large-sized and robust E. sussenbornensis is still present. Lycaon lycaonoides (Kretzoi, 1938), Hystrix refossa Gervais, 1852, and Cercopithecidae Gray, 1821 of African origin, Theropithecus Geoffroy, 1843 (Rook et al. 2004; Rook \& Sardella 2005) appear. During this temporal interval (1.3-1.6 Ma) in the quarries of Pirro Nord, the most ancient evidence of humans in Europe, testified by lithic artefacts, were found (Arzarello et al. 2007).

\section{The Galerian Mammal Age}

The transition between the typical Villafranchian faunas and the Galerian ones (more modern and without Pliocene taxa) was a gradual phenomenon that lasted over a span of about 500000 years.
During this period, new species, typical of steppic/ prairie environments, reached in Italy from the east and from Central Europe joining the Villafranchian species that progressively disappeared.

The appearance of Praemegaceros verticornis (Dawkins, 1872) has been choosen as the bioevent that marks the beginning of the Galerian Mammal Age (Gliozzi et al. 1997). This species is a large sized cervid that was reported for the first time in the Colle Curti (Marche) local fauna, which has also been correlated to the base of the Jaramillo subchronus (about 1.1 Ma). This moment, well-known through the marine isotopic record and through continental pollen diagrams, represents another important point of radical transformation of the climatic and vegetational cycles ("mid-Pleistocene revolution"). In fact, the passage to a phase characterized by long glaciations is observed with 100000 years cycles. The difference between the temperatures during glacial and interglacial phases becomes more pronounced (Leroy 2007). In northern Italy, the macro- and microfloristic findings of Ranica (Ravazzi et al. 2005) demonstrated that, during the glacial phase corresponding to the Jaramillo subchron (MIS 30), the flora was already represented by species that are still living in the present day (e.g., Larix decidua Miller and Picea abies (Linnaeus). In the Ranica site a cold, steppic phase is well documented in which an Alcin was found (Cervalces latifrons (Johnson, 1874)); nevertheless, an arboreal covering remains present at the foot of the Alps even during this phase. On the contrary, in Central Italy, the pollen diagrams of Colle Curti and Cesi (Bertini 2000) show high percentages of herbaceous forms, a clear evidence of more open vegetation. Furthermore, this vegetation was replaced by arboreal vegetation during short temporal intervals. The fauna of early Galerian is relatively scarce, but it has innovative elements, especially among the micromammals (Kotsakis et al. 2003). Many Villafranchian species still persist: Pachycrocuta brevirostris Aymard, 1846, Panthera gombaszoegensis and Homotherium Fabrini, 1890 among the carnivores; Stephanorhinus cf. hundsheimensis and Hippopotamus antiquus among the herbivores.

Three F.U.'s are recognizable within the middle Galerian faunas on the basis of the percentage of 
leftover (Villafranchian) forms and the percentage of new forms (that entered or locally differentiated). During this temporal interval the most remarkable and documented faunal renewal occurred. In the Slivia F.U., dated about 850000 years ago, Axis eurygonos is still present and several first occurrences are recognizable: Cervus elaphus acoronatus (Beninde, 1937) (an archaic subspecies of the red deer), Sus scrofa priscus Goldfuss, 1832 (the first wild boar), Bison cf. schoetensacki Freudenberg, 1910 (an archaic form of bison), Stephanorhinus hundsheimensis (a small-sized rhino of open lands), more advanced forms of Mammuthus (M. cf. tamanensis (Dubrovo, 1964), M. cf. trogontherii Brookes, 1828), the first archaic form of Elephas (E. cf. antiquus Falconer \& Cautley, 1847), Crocuta crocuta Erxleben, 1777 (the spotted hyena) and Ursus deningeri Linnaeus, 1758. Pachycrocuta Kretzoi, 1938 and Megantereon Croizet \&Jobert, 1828 disappear.

In the slightly more recent Ponte Galeria F.U. (about 750000 years ago) (Petronio \& Sardella 1999), Bos galerianus Petronio \& Sardella, 1998, a bubaline bovid, has its first occurrence and, among the megacerini there is Megaloceros savini Brookes, 1828. Elephas antiquus, which will survive until the last glacial, and Mammuthus trogontherii both spread out.

The Isernia F.U., dated at around 550-600 000 years ago (Coltorti et al. 2005), is characterized by the first occurrence of Panthera fossilis (Reichenau, 1906) (a primitive lion), by Equus ferus Linnaeus, 1758 (= Equus caballus, Gliozzi et al. 1997), by several Caprinae (Hemitragus Hodgson, 1841 and Ovis antiqua Linnaeus, 1758), by another largesized Cervidae (Praemegaceros solilhachus (Robert, 1829)), by an archaic fallow deer (Dama clactoniana (Falconer, 1868)) and by a massive form of rhino (Stephanorhinus kirchbergensis (Jäger, 1839)) (Billia \& Petronio 2009). This F.U. is also characterized by the dispersal of Bison schoetensacki.

During the late Galerian (Fontana Ranuccio F.U., $460000-350000$ years ago) the faunal renewal is completed. The last Villafranchian species disappear (except possibly Homotherium) and numerous species appear: Cervus elaphus eostephanoceros Di Stefano \& Petronio, 1993 (a more advanced form of red deer characterized by a slight hint of a crown), Ursus arctos Linnaeus, 1758 (the brown bear), Hippopotamus amphibius Linnaeus, 1758, similar to the recent Hippopotamus (Petronio 1995) and less adapted to the aquatic life respect to Hippopotamus antiquus, Bos primigenius Bojanus, 1827 (the auroch). Considering the rhinos, a prairie form (Stephanorhinus hemitoechus (Falconer, 1868)) spreads out and the forestal form (Stephanorhinus kirchbergensis) is still present.

\section{The Aurelian Mammal Age}

The beginning of the Aurelian Mammal Age, can be placed approximately in correspondence of MIS 10. This Mammal Age sees the appearance of the taxa that represent the core of the present day mammal fauna. Changes involve forms typical of all environments: forest, open lands and intermediate environments. The mammal communities become more and more similar to the modern ones, with the diminishing of large-sized forms and the increase of medium and small-sized ones.

The characteristics of the vegetation in Central Italy have been very well documented by long pollen diagrams (Follieri et al. 1988) and by the findings of macrofossils concentrated in some interglacial deposits. On the outskirts of Rome the interval is characterized by predominantly open vegetations with relatively brief forestal phases (Roma I, Roma II, Roma III, Eemian and St. Germani I), which only correspond to $1 / 10$ of the time.

In the early Aurelian, the Torre in Pietra F.U. (about MIS 10-8), the modern wolf, Canis lupus Linnaeus, 1758, the cave bear, Ursus spelaeus Rosenmüller \& Heinroth, 1794, the giant deer, Megaloceros giganteus Blumenbach, 1799 and the cave lion (Panthera spelaea (Goldfuss, 1810)) appear for the first time. Together with these species, different local subspecies of Cervus elaphus are present; they show endemic features, witnessed by the particular archaic structure of the antlers. In the deposits referable to this period Elephas antiquus and Bos primigenius are constantly present; they are the most abundant species, followed by rhinos, horses, deer, hippos and scarce carnivores; and in some sites even the presence of cold avifauna was found.

In the assemblages of the middle Aurelian, referable to the Vitinia F.U., an archaic subspecies 
of the modern fallow deer, Dama dama tiberina Di Stefano \& Petronio, 1997, and a small-sized Equidae with slim limbs, Equus hydruntinus Regalia, 1904, appear. Different climatic conditions characterized the peninsula: the mild climate of the Tyrrhenian mountainside allowed the diffusion of Macaca sylvanus, while the more arid conditions of the Adriatic side enabled the ibex (Capra ibex Linnaeus, 1758) and chamois (Rupicapra rupicapra Linnaeus, 1758) to reach the south part of Apulia and with the climate cooling down, mammoths of the Mammuthus chosaricus group spread out.

The late Aurelian is characterized by a series of important climatic events that influenced the faunal composition, with the latitudinal migrations and the reduction of the area of many species. In Italy, the faunal assemblages of this period are difficult to define due to local microclimatic factors, which seem to assume a particular importance with the last glacial drawing near.

In the first part of the late Aurelian (MIS 5) many taxa found in the preceding Faunal Units are still present: among the pachyderms there were Elephas antiquus, Mammuthus chosaricus Dubrovo, 1966, Stephanorhinus hemitoechus and, rarely, Stepahonorhinus kirchbergensis and Hippopotamus amphibius. Very common in mountain environments Capra ibex, Rupicapra rupicapra, and Marmota marmota (Linnaeus, 1758) are present, which are associated to many Felidae Gray, 1821 and a large-sized wolf. Bos primigenius and Equus ferus are very abundant, and less frequent is Equus hydruntinus. Amongst the Artiodactyla some changes can be recorded in Cervidae: during the MIS 5, the red deer is present for the first time with the subspecies Cervus elaphus elaphus, and the fallow deer (Dama dama dama (Linnaeus, 1758)), derived from Dama dama tiberina, appears (Di Stefano \& Petronio 2000; Petronio et al. 2007).

The first occurrence of these Cervidae, together with a rich mammal fauna of temperate-warm climate, allowed the new F.U. of Melpignano (Apulia) to be instituted and a probable temporal interval between $0.120 \mathrm{Ma}$ and $0.070 \mathrm{Ma}$ to be set for this Unit (Petronio et al. 2007).

The first occurrence of Coelodonta antiquitatis (Blumenbach, 1799), Mammuthus primigenius
(Blumenbach, 1799) and of Marmota primigenia (Kaup, 1839) seem to be the bioevents that can define a successive temporal interval that goes from MIS 4 (the first sign in Italy of these "cold" mammals) to MIS 3, in which almost all the large pachyderms gradually disappear from the peninsula (Petronio et al. 2007). The first presence of Coelodonta antiquitatis, together with Stephanorhinus hemitoechus, Elephas antiquus, Cervus elaphus elaphus, Dama dama dama, Equus hydruntinus, Vulpes vulpes (Linnaeus, 1758) and other carnivores such as Ursus arctos and Gulo gulo (Linnaeus, 1758) and birds like Nyctea scandiaca (Linnaeus, 1758), enabled the Faunal Unit of Ingarano to be defined (the last F.U. of the Aurelian Mammal Age) and a probable temporal interval between $0.070 \mathrm{Ma}$ and $0.035 \mathrm{Ma}$ to be set for this unit.

In this chronological interval first Hippopotamus amphibius and Elephas antiquus disappear, followed later by Stephanorhinus hemitoechus. Equidae become abundant with ibex and chamois, which expand their territory, while the fallow deer and the wild boar survive in the southern regions of the peninsula (Petronio et al. 2007). Some "cold taxa", of which are Pinguinus impennis (Linnaeus, 1758), Myotis dasycneme (Boie, 1825), Sicista betulina (Pallas, 1779), Mustela erminea Linnaeus, 1758, Alces alces (Linnaeus, 1758) and Rangifer tarandus (Linnaeus, 1758), make their appearance (Capasso Barbato et al. 1991).

With the last pleniglacial (MIS 2) almost all the large mammals progressively disappear. During the maximum ice expansion the last occurrences of Dama dama dama, Crocuta crocuta, Panthera pardus Linnaeus, 1758 and Ursus spelaeus are recorded. In the late glacial, Megaloceros giganteus, Bison priscus (Bojanus, 1827) also disappear along with almost all the "cold" mammals (in the Alps, however, the white hare and the ermine still exist today). Lutra lutra (Linnaeus, 1758) and Martes foina (Erxleben, 1777) probably enter in the peninsula only at the beginning of the Holocene (Sommer \& Benecke 2004; Petronio et al. 2007) while the last occurrences in Italy of the elk (Sala pers. com.), the cave lion and wild Equidae are recorded (Petronio et al. 2005, 2007). 


\section{ANALYSIS AND COMPARISON OF THE BIOCHRONOLOGICAL DATA FROM CENTRAL ITALY WITH DATA FROM THE WHOLE PENINSULA}

\section{PREMISE}

Before the analysis of the data concerning the central part of the Italian peninsula, it is worth discussing some methodological issues that will support the analytical results.

The values corresponding to the Mammal Ages from the Villafranchian to the Aurelian are quite similar to the values of the entire Italian peninsula. In an analysis of great detail, instead, considering the single Faunal Units during the three million years, sometimes data from Central Italy is missing. This is only pertinent to the Pliocene and the earliest part of the Pleistocene; for the Middle and Late Pleistocene (an exception being made for the Slivia F.U., which in Central Italy is not represented in any fossiliferous site), the abundance of data enabled the deposits of the whole Italian territory (excluding the islands) to be compared. In this case, the paleobiological survey of the entire Peninsula is similar to that of the central part.

Considering that - from the Galerian to the Aurelian (during the last one million years) - the structural uplift of the Apennines enabled a watershed line to be identified, potential environmental differences between the Tyrrhenian and Adriatic regions have tried to be distinguished.

In this analysis, the macromammals were taken into account because the data concerning micromammals, birds and, sometimes, reptiles are particularly scarce in the Pliocene and in the earliest Pleistocene. As a matter of fact in the Middle Pleistocene and, especially, in the Late Pleistocene, data on micromammals become abundant, and they reflect the environmental changes very well; nevertheless, the same kind of environmental variations can be pointed out by herbivorous macromammals that are very abundant during the entire temporal interval; therefore, correlating only this group of animals to the floristic variation of the peninsula was preferred. In future papers data concerning micromammals will be able to be examined and it will be interesting to compare those analyses with the data of macromammals; this kind of comparison was already carried out on the most recent phases of the late Villafranchian (Farneta and Pirro F.U.'s) (Kotsakis et al. 2008).

These same macromammals were divided into large herbivorous pachyderm, herbivores and carnivores. All the carnivores were taken into account as a single group. During the Late Pliocene and Early Pleistocene, remains of the large-sized carnivores, characterized by ambush and run hunting systems, are present. Instead, during the Middle Pleistocene and, in particular, the Late Pleistocene, mediumand small-sized carnivores seem to prevail.

\section{DISCUSSION}

All the following statistical analyses are obtained from Tables 1-6 (see Appendices) relative to the faunal assemblages found in several sites of Central Italy, and they are assigned to the Faunal Units from the early Villafranchian to the late Aurelian. All data are extracted from: Fabiani (1922), Graziosi (1928, 1944), Del Campana (1954), Radmilli et al. (1955), Segre \& Ascenzi (1956), Acanfora (1962), Grifoni \& Radmilli (1964), Cremonesi (1968), Tozzi (1970, 1974), Pitti \& Tozzi (1971), Cassoli (1976), Pitti et al. (1976), Radmilli (1977), Caloi et al. (1979, 1980, 1989), Giustizia (1979), Bianucci (1980), Palmarelli \& Palombo (1981), Capasso Barbato et al. (1982, 1998), Radi (1982), Bietti (1984), Bulgarelli \& Tagliacozzo (1984), Cazzella \& Moscoloni (1984), Segre et al. (1984), Segre Naldini (1984), Vitagliano (1984), Caloi \& Palombo (1987), Alhaique et al. (1988, 1998), Wilkens (1991), Bologna et al. (1994), Castelletti et al. (1994), Ruffo (1995), Alhaique (1996), Boscato (1996), Cerilli \& Brocato (1998), Cilli et al. (1998), Rustioni et al. (1999), Boscato et al. (2001), Di Canzio \& Petronio (2001), Palombo et al. (2002), Petronio et al. (2002), Di Canzio et al. (2003), Arzarello et al. (2004), Guerreschi et al. (2005).

In the first diagram (Fig. 2A) the quantity of taxa is influenced by the number of the studied sites; in particular, the minimum values for the taxa relative to the early Villafranchian and to the early and late Galerian are due to the low number of sites found in Central Italy. The MIS 2 is an exception, in which a minimum value for the number of taxa corresponds to a higher number of sites; this ex- 

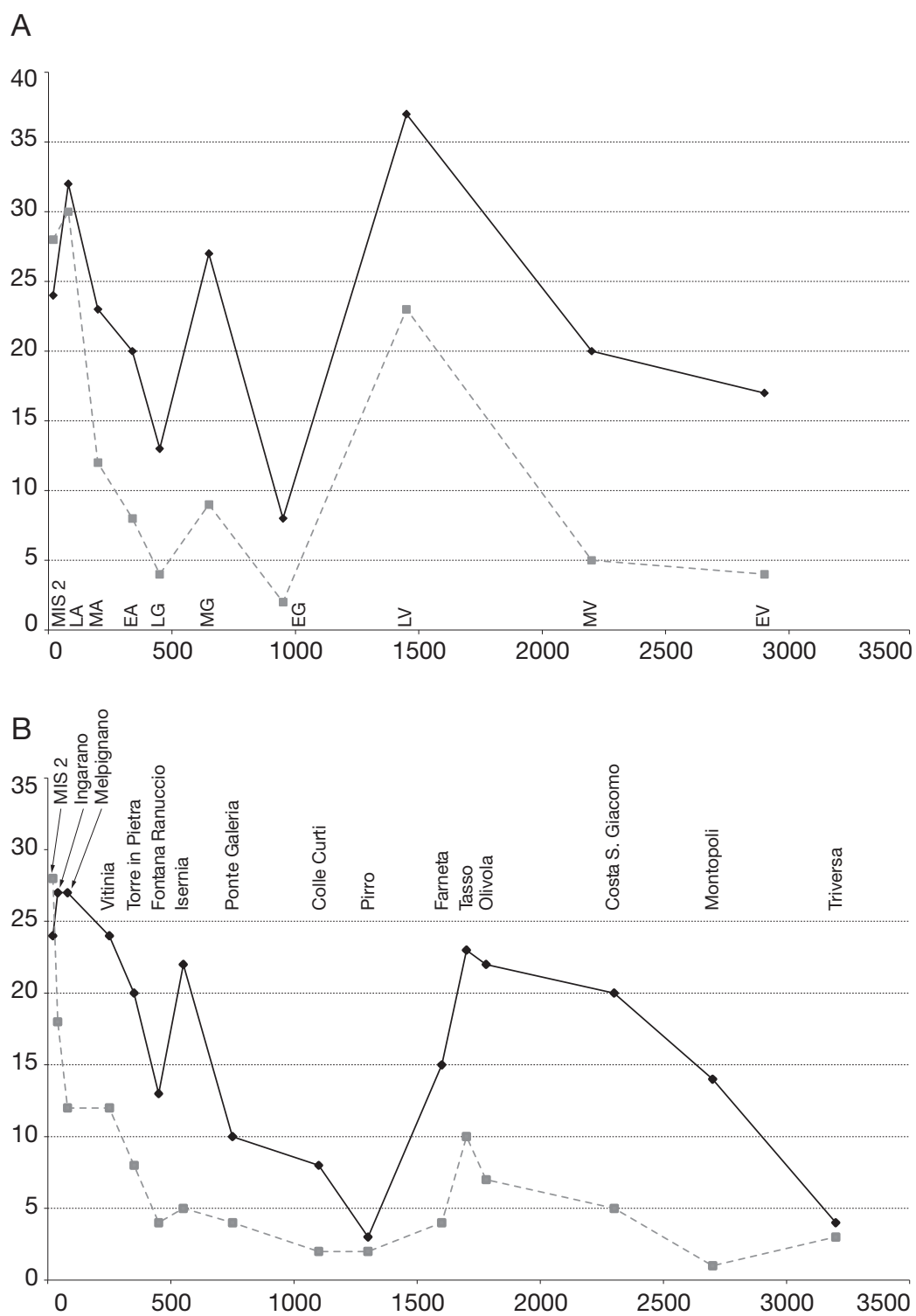

FIG. 2. - A, frequency curves of the taxa found in the Mammal Ages of Central Italy (continuous line); quantity of the fossiliferous sites (dashed line); B, frequency curves of the taxa found in the Faunal Units of Central Italy (continuous line); quantity of the fossiliferous sites (dashed line). Abbreviations: MIS 2, Marine Isotopic Stage 2; LA, late Aurelian; MA, middle Aurelian; EA, early Aurelian; LG, late Galerian; MG, middle Galerian; EG, early Galerian; LV, late Villafranchian; MV, middle Villafranchian; EV, early Villafranchian. In abscissa, time in $\mathrm{Ma}$; in ordinate, number of taxa.

ceptional situation is due to the disappearance of the pachyderms and of the large-sized herbivores, but it is compensated by a high number of studied sites in the final part of the Late Pleistocene.
The same trend, in a more detailed way because it is referred to the F.U.'s, is recognizable in the second diagram (Fig. 2B): the number of species existing in the different temporal intervals is highly elevated es- 
A

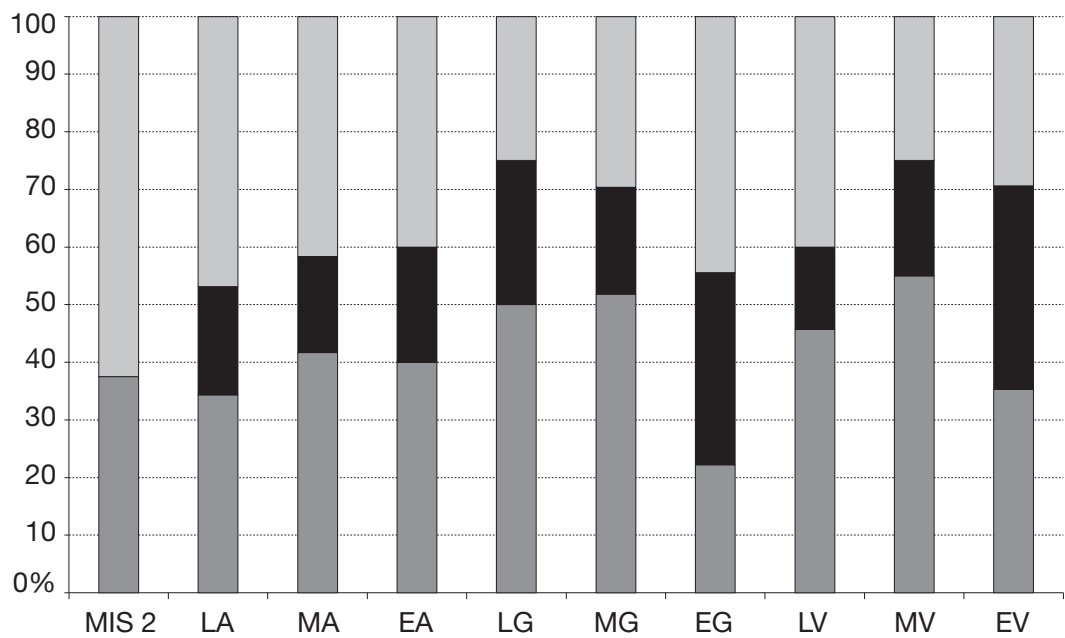

B

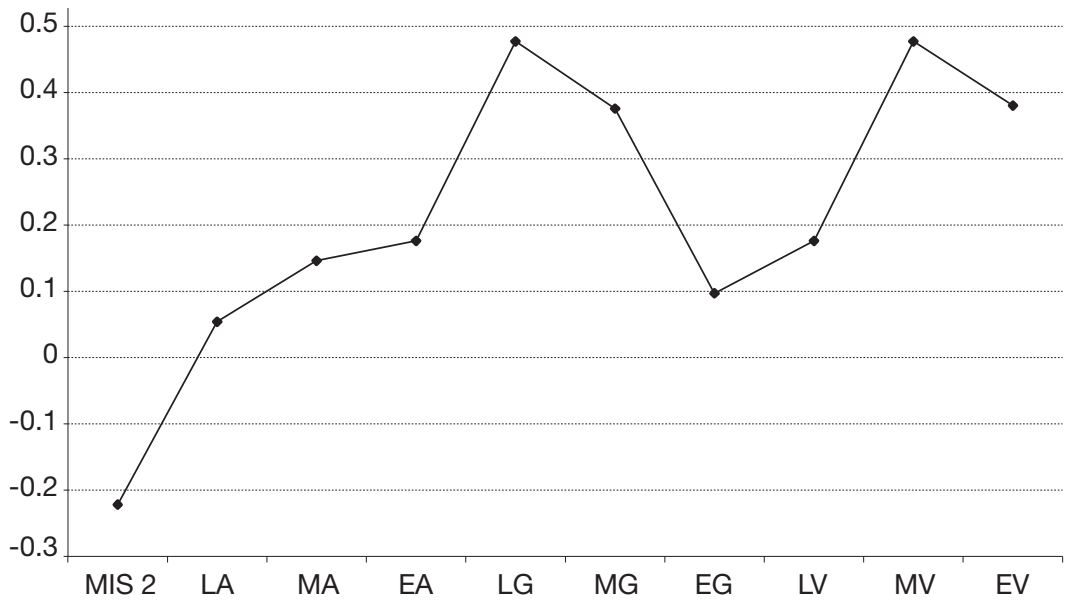

FIG. 3. - A, frequency histograms of the quantity of herbivorous taxa (darkgrey), pachyderms (black) and carnivores (lightgrey) living in the Mammal Ages of Central Italy; B, medium and large-sized herbivores and carnivores ratio (on logarithmic scale) for Central Italy. Abbreviations: LA, late Aurelien; MA, middle Aurelian; EA, early Aurelian; LG, late Galerian; MG, middle Galerian; EG, early Galerian; LV, late Villafranchian; MV, middle Villafranchian; EV, early Villafranchian; MIS 2, Marine Isotopic Stage 2.

pecially in the first part of the late Villafranchian; it is low for the Pirro and Colle Curti F.U.'s, and it increases during the Galerian and the Aurelian, even because it increases parallel to the number of sites taken into account. On the whole, the biodiversity increases from the early Villafranchian to the late Aurelian.

A different statistical analysis was carried out (Fig. 3A) (always in the long temporal interval comprised between the Middle Pliocene and MIS 2), grouping the herbivorous taxa (bottom), the pachyderms (middle) and the carnivores (top).

The medium and small-sized herbivores (at the bottom) account for about $50 \%$ of all the taxa, excluding the minimum value of the early Galerian due to the presence in the territory of Central Italy of only two mammal sites (Colle Curti and 


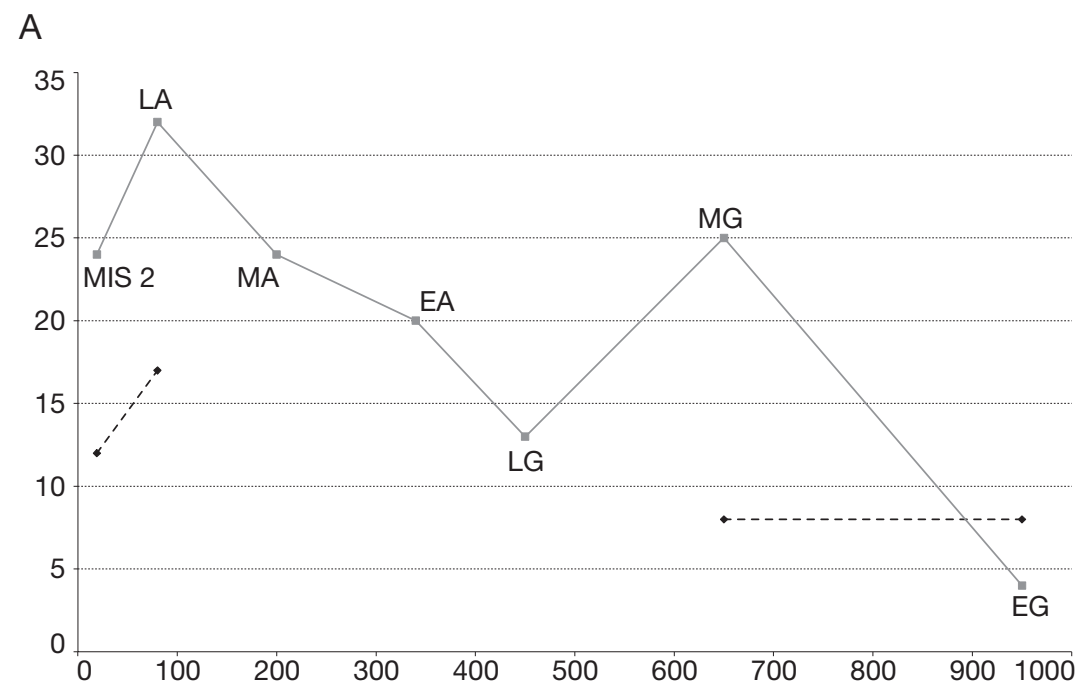

B

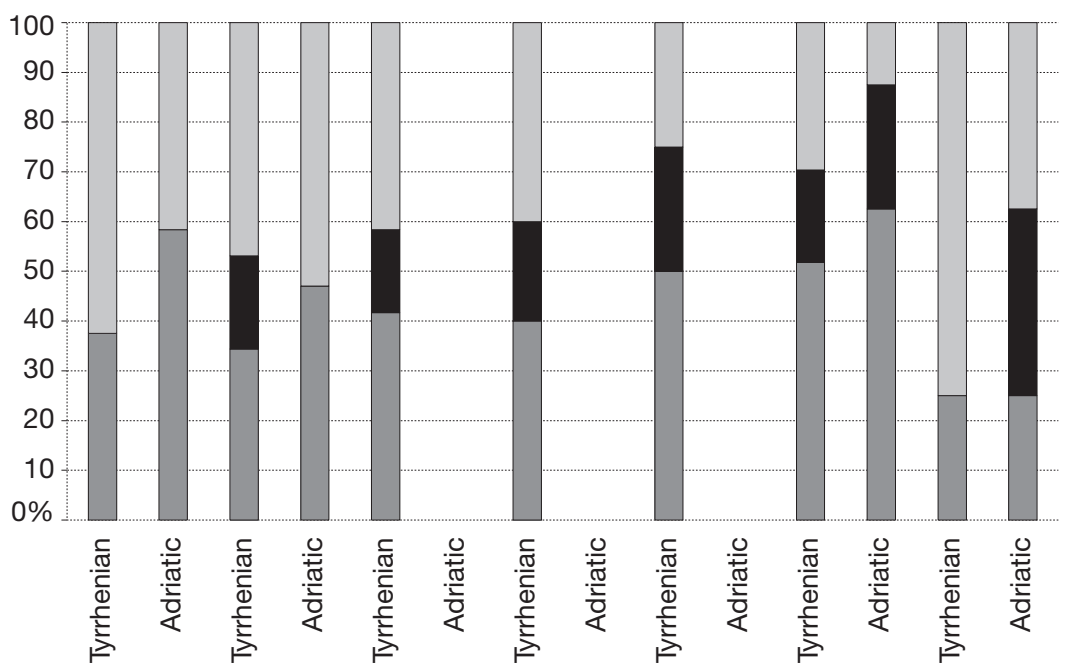

FIG. 4. - A, frequency curves of the taxa found in the Mammal Ages of the Tyrrhenian side (continuous line) and of the Adriatic side (dashed line) in Central Italy; in abscissa the time in thousands years, in ordinate the number of taxa; B, frequency histograms of the quantity of herbivorous taxa (darkgrey), pachyderms (black) and carnivores (lightgrey) living in the Tyrrhenian and Adriatic side of Central Italy. Abbreviations : LA, late Aurelien; MA, middle Aurelian; EA, early Aurelian; LG, late Galerian; MG, middle Galerian; EG, early Galerian; MIS 2, Marine Isotopic Stage 2.

Monte Peglia); as in Gliozzi et al. (1997), the site of Monte Peglia is considered to belong to the Colle Curti F.U. because the micromammals show characters compatible with this temporal interval, even if the macromammals are certainly not classifiable.
Pachyderms, after an abundance of many forms in the early and middle Villafranchian, present themselves in quite abundant percentages to the late Aurelian, and then they disappear completely with the last glacial episode. Even in this case, the analysis of the only available site (Colle Curti) 


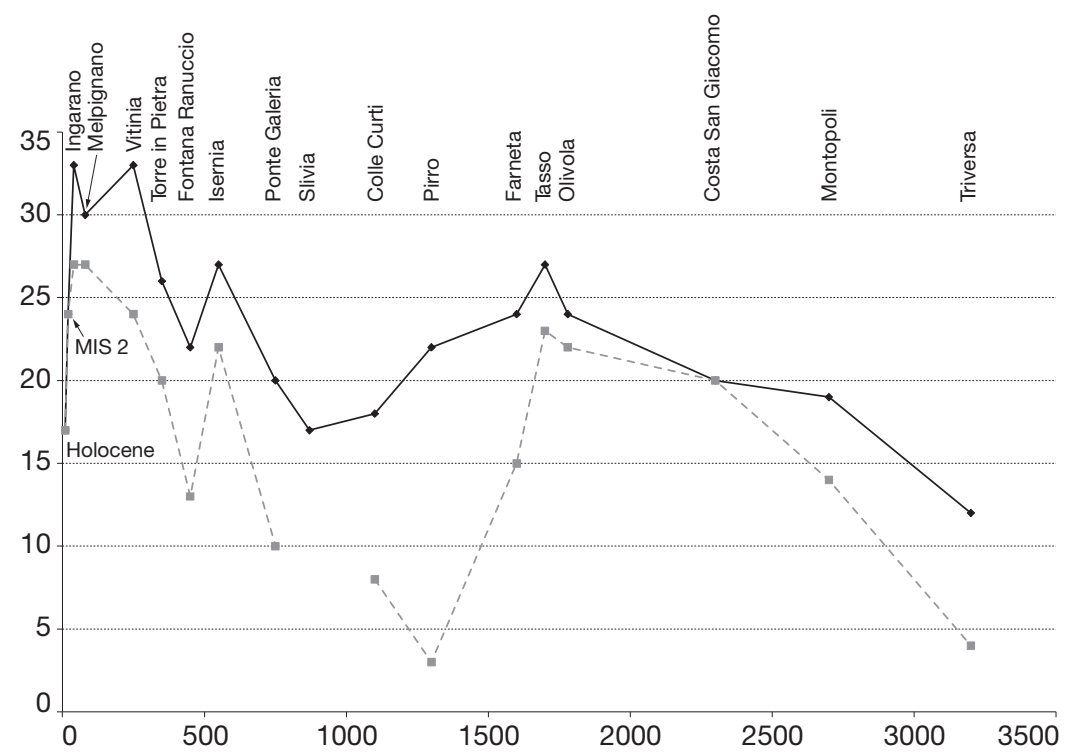

FIG. 5. - Frequency curve of the quantity of species comprised in the temporal interval of the Faunal Units for Italy (continuous line) and for Central Italy (dashed line); in abscissa the time in thousands years, in ordinate the number of taxa. Abbreviations: MIS 2, Marine Isotopic Stage 2.

alters the percentage of the occurrences in this temporal interval.

The histograms (UP) indicating the percentage of carnivorous mammals seem to have a peculiar trend: their diversity seems to be low in the first part of the Villafranchian, whereas it increases from the late Galerian to the late Aurelian. The abundance of the carnivorous mammals during the late Villafranchian and of the Galerian is probably due to the presence of medium- and large-sized carnivores characterized by an ambush hunt-way and to the presence of large-sized predator runners. The large number of Mustelidae and other small predators in the Aurelian changes the percentages to the advantage of the carnivores during the last 300000 years. Nevertheless, it cannot be excluded that this trend is somehow altered by the different number of findings, which is relatively low in the early and middle Villafranchian and in the early Aurelian, whereas it is relatively high and it is contemporaneous to the human presence during and after the late Aurelian.

The following diagram (Fig. 3B) (the $\mathrm{x}$ axis shows the herbivores/carnivores ratio; the y axis shows the Mammal Ages; the percentages are expressed on logarithmic base) points out the same phenomenon: the herbivores/carnivores ratio tends to decrease constantly to the advantage of the carnivores during the last part of the Pleistocene for the same reasons we explained before.

Taking into account the Middle Pleistocene fossiliferous localities of the Tyrrhenian and Adriatic sides (Fig. 4A), it can be observed that the number of taxa from the Tyrrhenian side (continuous line) basically corresponds to the same curve that is found in Central Italy for the same temporal interval. Data from the Adriatic side (dashed line) are, instead, very incomplete for the Galerian and show the same trend on the Tyrrhenian side during the second part of the Aurelian.

Even for the Galerian, taxa were, once again, grouped into herbivores, pachyderms and carnivores. Results of the findings on the two sides are shown in Figure 4B: we can only compare the last 200000 years because in the central part of the diagram, data from the Adriatic side, are lacking; in the last one million year the relative increase of the small and medium-sized carnivores from the Galerian to MIS 2 is more evident. 

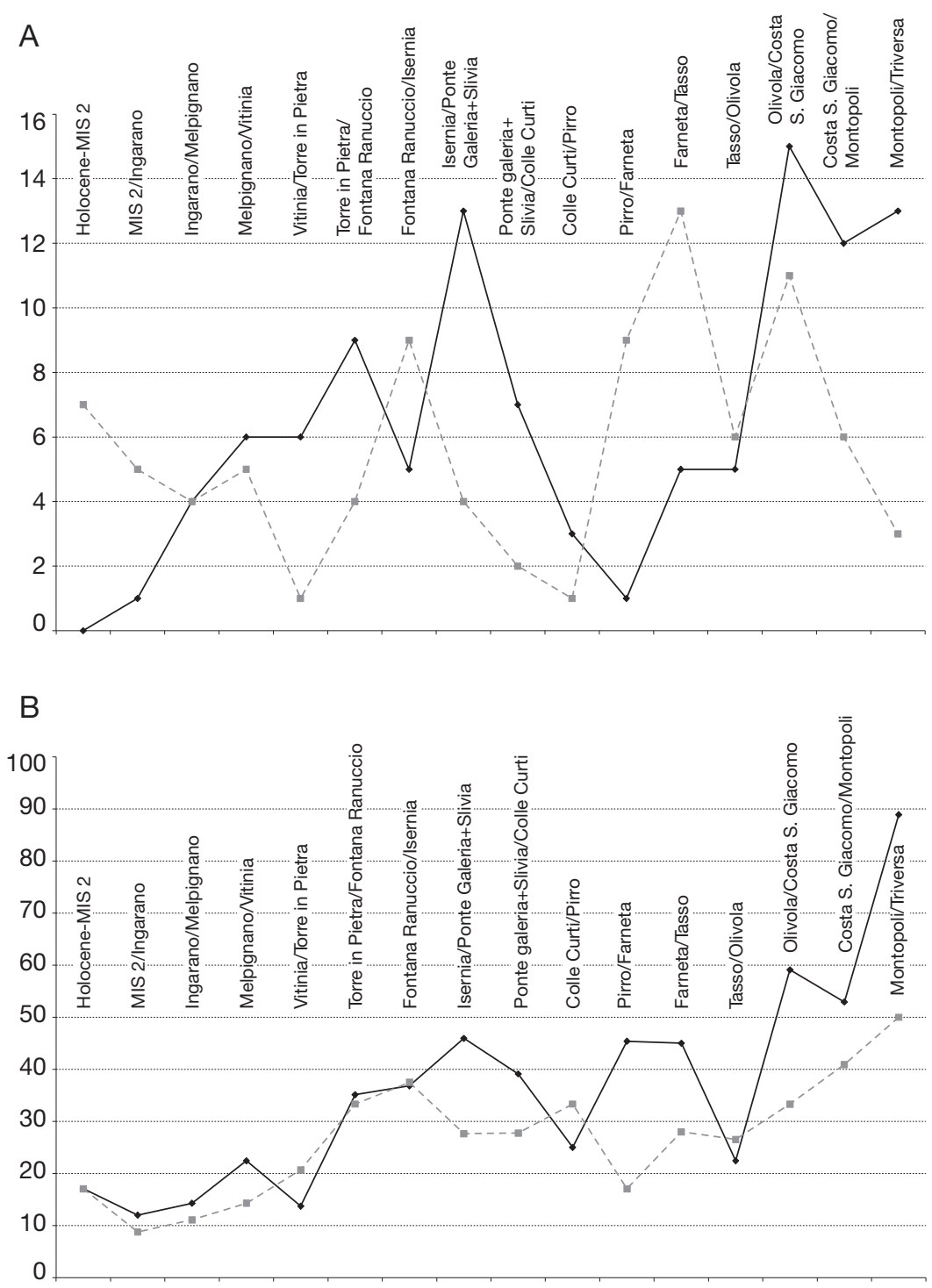

FIG. 6. - A, frequency curve of the quantity of First Occurrences (continuous line) and Last Occurrences (dashed line) comprised in the temporal intervals of the Faunal Units for Central Italy (in ordinate the number of taxa); $\mathbf{B}$, comparison between the trend of the turnover curves calculated for Italy (dashed) and for Central Italy (continuous line) (in ordinate the values of the turnover index). Abbreviation: MIS 2, Marine Isotopic Stage 2.

In Figure 5 the curve corresponding to the number of taxa from Central Italy (dashed line) and the curve corresponding to the number of taxa from the entire peninsula (continuous line) in the distinct Faunal Units are compared (adding the three new Faunal Units not yet mentioned in Gliozzi et al. 1997: Ponte Galeria
[Petronio \& Sardella 1999]; Melpigano and Ingarano F.U.'s [Petronio et al. 2007]). The trend seems quite similar to the F.U. of Isernia to the Aurelian (MIS 2 ), whereas it diverges from the total curve in the Early Pleistocene (Faunal Unit of Slivia) and in the Pliocene, because of the missing data. 
A

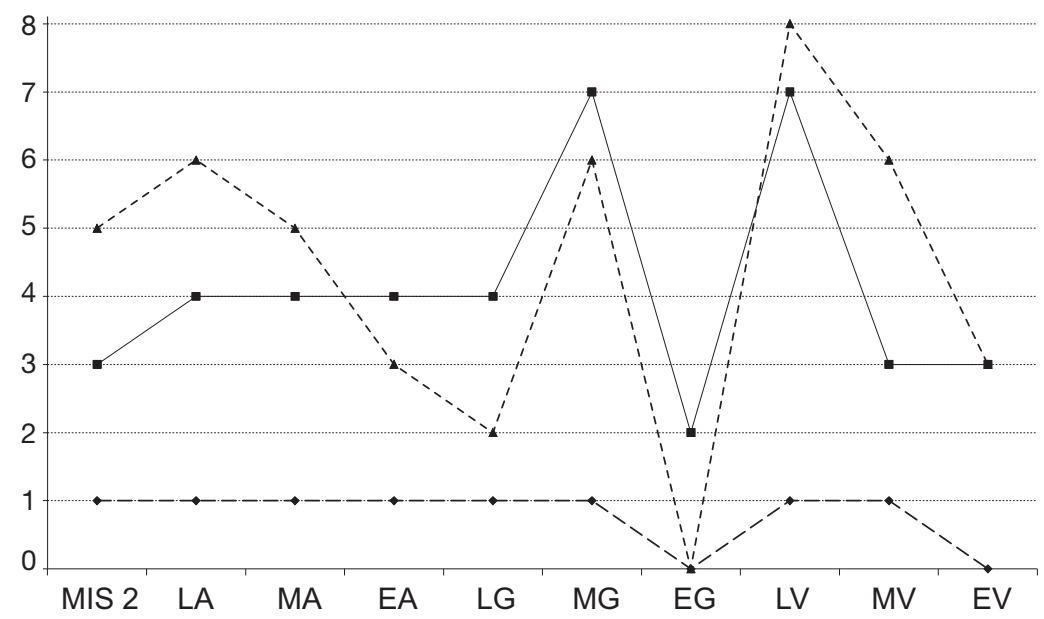

B

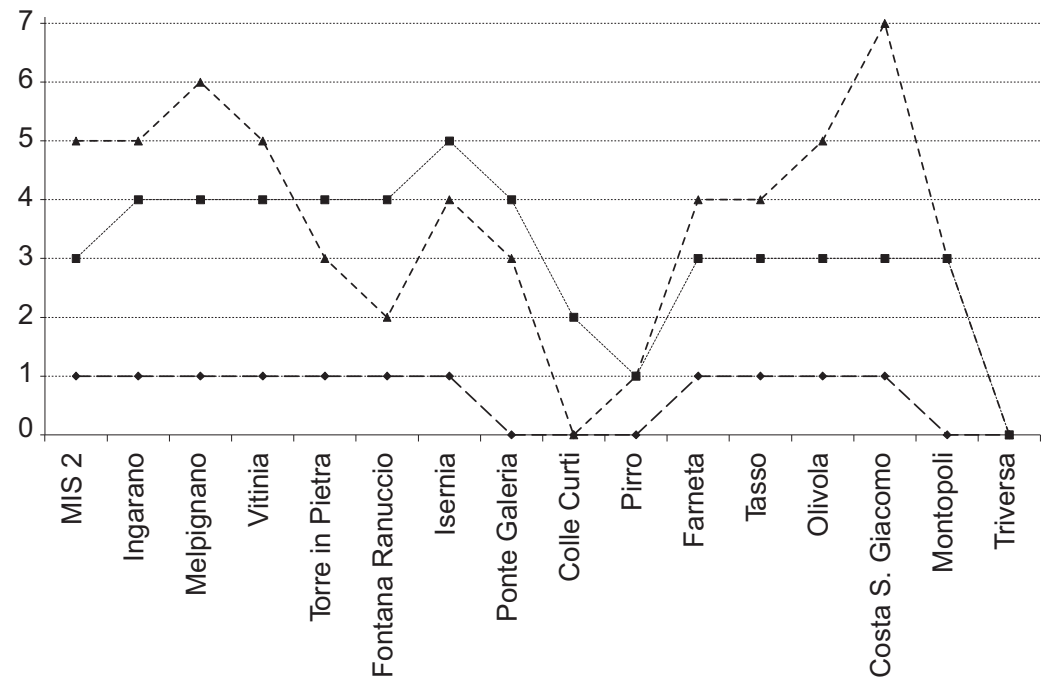

FIG. 7. - A, frequency histogram of the quantity of herbivorous brachydonts, mesodonts and hypsodonts for the Mammal Ages of Central Italy; B, frequency histogram of the quantity of herbivorous brachydonts, mesodonts and hypsodonts for each Faunal Unit of Central Italy. Abbreviations: MIS 2, Marine Isotope Stage 2; LA, late Aurelian; MA, middle Aurelian; EA, early Aurelian; LG, late Galerian; MG, middle Galerian; EG, early Galerian; LV, late Villafranchian; MV, middle Villafranchian; EV, early Villafranchian. In ordinate the number of taxa.

The following Figure 6A shows the trend of the taxa alternating in Central Italy: the continuous line represents the number of first occurrences (FO) of macromammal taxa and the dashed line represents the quantity of last occurring taxa (LO) at the passage between the Faunal Units; the number of taxa is expressed on the $\mathrm{x}$ axis.

The Turnover Indexes (formulas TI = \%fo + \%lo/2; $\%$ fo $=$ fo/Rm*100; Rm $=\mathrm{N}-($ fo+lo/2) $)$ of the numerous taxa for the entire peninsula (dashed line) 


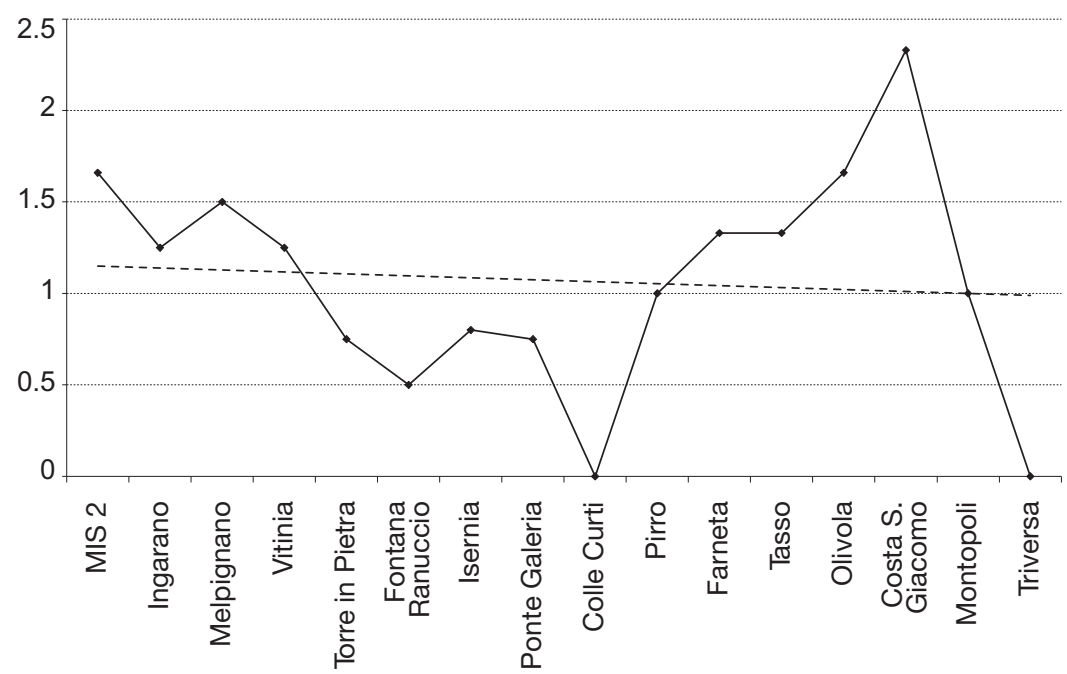

FIG. 8. - Hypsodonts and mesodonts ratio in the Faunal Units showing the tendency line (dashed line). In ordinate the values of the ratio between hypsodont and mesodont taxa. Abbreviation: MIS 2, Marine Isotope Stage 2.

and for Central Italy (continuous line) are compared in the following diagram (Fig. 6B; Table 7) through the entire temporal frame reflected in this paper; if the curve that represents the whole peninsula is compared to the one obtained in Sardella et al. (1998), slight differences can be noticed, due to how much the data (those relative to the sites and the taxa) have been modified, which has been brought on during the last ten years. The turnover curve, in the temporal intervals referable to Central Italy, diverges from the general one especially in the part related to the early and middle Villafranchian. In fact, this curve shows prevalently higher values (see also Fig. 6A) because, considering the low number of fossiliferous sites, a higher number of first occurring taxa and a lower number of last occurring taxa is found.

Taxa were divided into brachydonts (Suidae), mesodonts (Cervidae) and hypsodonts (Equidae and Bovidae) in order to have a better picture of which herbivores lived in Central Italy from the Pliocene to the Holocene (Fig. 7A): while brachyodonts are in small percentage and almost always present, mesodonts are characterized by a good percentage of species that, only in the late Aurelian, tends to decrease. Hypsodonts show a more articulated trend: they first form a block and then show a minimum at the end of each Mammal Age. A remarkable increase of the hypsodonts, in respect to the mesodonts, characterizes the middle and late Villafranchian and the Aurelian.

The same trend, can be seen in the previous diagram, but more detailed, and it is obtained considering each Faunal Unit (Fig. 7B): the remarkable prevalence of the hypsodonts in respect to the mesodonts in the Middle and Late Pleistocene is highlighted.

The simple hypsodonts/mesodonts-ratio is pointed out in Figure 8, wherein, above the value 1, the temporal intervals characterized by the prevalence of hypsodonts are reported. This could indicate that the long temporal intervals in which the hypsodonts clearly prevail (e.g., the Montopoli and Pirro F.U.'s, the Aurelian M.A.) correspond to the prevalence of the open lands.

\section{CONCLUSIONS}

Some conclusive considerations from the quantitative analysis of the macromammal taxa found in Central Italy can be pointed out.

The number of macromammal species present in Central Italy from the early Villafranchian to the 
late Aurelian is fairly close to the trend defined for all of the Peninsula's deposits and it seems to lean towards a moderate increase (Fig. 2); the lowest values of the number of recorded taxa, therefore, the lower values of biodiversity, coincide, as was logically expected, with the passage of one Mammal Age to another. The rise of the same biodiversity in the entire temporal arc considered, but much more emphasized from the Galerian to the late Aurelian, can depend on different factors, one of which could be connected to structural factors: the progressive geological and physiographic development of the Peninsula provided to diversify the ecological niches and/or microclimates. In fact, during the Pliocene and earliest Pleistocene (early and middle Villafranchian biochrons), it is possible to observe a environmental uniformity which will successively tend to decrease in the last one million year. This change enabling the diffusion and the adaptation of a greater number of species.

On the contrary, the paleobotanical data provide clear evidence of a progressive decrease in number of arboreal species from the Middle Pliocene to the end of the Early Pleistocene; therefore, the biodiversity of the arboreal plants seems to initially follow a trend that is opposed to the preceding that was recorded for the mammals. This can been explained by the fact that most of these arboreal species represented evergreen forms connected to groups of "subtropical", humid forests, documented for the last time in the Gelasian in Central Italy, in association with mammals from the Montopoli Faunal Unit. In Calabria, even with an impoverished flora, the "subtropical", humid forest, instead, continues until the beginning of the Early Pleistocene (Olivola and Tasso Faunal Units).

The palaeobotanical documentation of the progressive increase of open areas, which until the end of the Piacenzian had to be nearly all absent or limited to the fluvial areas, is particularly important. From the beginning of the Piacenzian-Gelasian transition (apart from an evident dropping of the annual mean temperature with the presence of conifer in the planes) a first sign of the vegetation opening up is recorded (Bertini 2006), which is found in the macromammal renewals of Toscana (Montopoli and Tasso-Olivola Faunal Units). From this point on the climatic oscillations caused rapid variations in the vegetation cover and a progressive disappearance of the floral elements that ill-suited for unstable conditions. Nevertheless, the pollen data indicate that the steppic phases, which are longer lasting and frequent in Southern Italy, developed only during some extreme glacial peaks (Russo Ermolli et al. 1995; Russo Ermolli 2000; Pontini \& Bertini 2000; Capraro et al. 2005).

The environmental differences in the Middle and Late Pleistocene between the Tyrrhenian and Adriatic area cannot be clearly defined; first because the Adriatic data, as noted above, is very sporadic; and second (independent of the poor Adriatic data), because the large part of the mammal taxa in Central Italy seem, nevertheless, to prefer the wider and diversified territories of the Tyrrhenian slopes. In cases where the Adriatic data is more complete, it is possible, however, to observe a trend that is fairly close to that of the Tyrrhenian; thus, one can conclude that the different climates of the two areas did not influence the trend of the taxa numbers or the abundance of populations.

In addition, a great number of herbivorous macromammals came from Asia, and it would perhaps be logical to expect a larger number of first occurrences (FO) of taxa in the Adriatic corridor; however, the analytical data confirm that the number of first occurrences in the Tyrrhenian side is greater. To justify this trend it can be hypothesized that in interglacial moments, the Tosco-Emilian Apennines had allowed the taxa coming from the northeast to enter and spread out into the more diversified Tyrrhenian side, whereas during the glacial periods the narrow Ligurian corridor, which functioned as a point of passage for some of the Italian species, needs to be revalued.

The migrations and the relative survival of the taxa on the Italian peninsula happened in a unique way: the species that entered late and with some difficulty through mountain passes during the climatic renewals tend to remain in Italy for a longer time and survive in the territory that became a refuge zone of continental Europe, and in several instances, even a sort of "trap". These particular conditions permit the Italian mammal fauna to at times develop morphotypes with a certain degree 
A

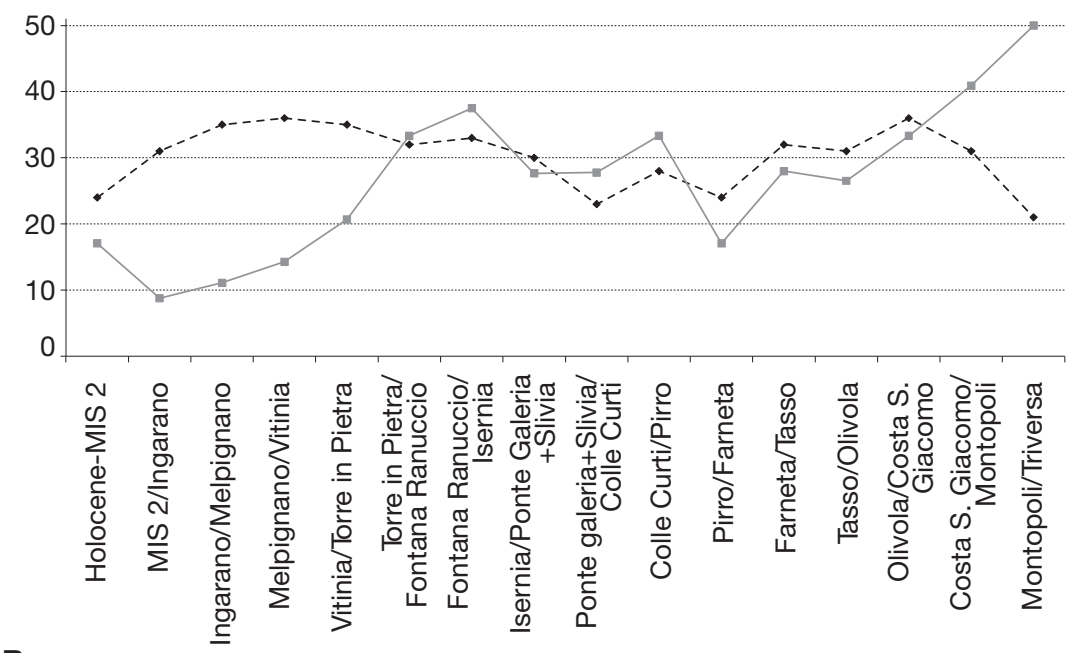

B

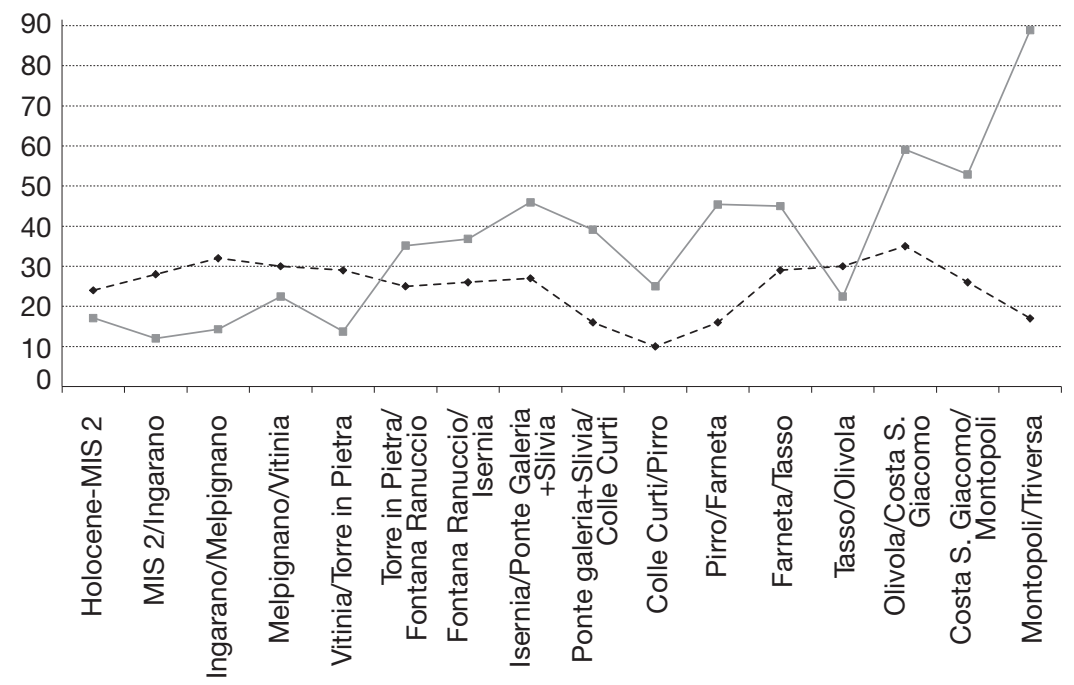

FIG. 9. - A, comparison between the quantity of taxa (continuous line) and the turnover indices (dashed line) for the temporal intervals comprised in the Faunal Units for Italy; B, comparison between the quantity of taxa (continuous line) and the turnover indices (dashed line) for the temporal intervals comprised in the Faunal Units for Central Italy. In abscissa the values of number of taxa and turnover index. Abbreviation: MIS 2, Marine Isotope Stage 2.

of endemism, which in some cases favors the appearance of particular taxa (Elephas antiquus italicus Osborn, 1931, Cervus elaphus rianensis Leonardi \& Petronio, 1974, C. e. aretinus Azzaroli, 1947, etc.). Due to the mild climate of the central part of the peninsula, the taxa were almost exclusively typical forms of Cervidae, like those of the Axis genus (with the species $A$. lyra, $A$. nestii and $A$. eurygonos) and the Dama genus that already established itself on the Peninsula in the Isernia Faunal Unit and that only in the Hoxinian late-interglacial does it reach Great Britain (Sutcliffe 1964), leaving sporadic 
traces of its existence throughout the European continent.

The biodiversity, which shows an increasing trend from the Galerian to the late Aurelian, has a sharp drop in the last 30000 years, probably due to the human activities that impacted the environment, together with the strong climatic cooling of the last pleniglacial and the subsequent abrupt warming.

The relative rise of the quantity of carnivorous mammals has already been pointed out (Fig. 3); here it can be added that the majority of carnivorous in the last 500000 years included predators that are of medium and small dimensions: considering even in this case that much data is missing for the oldest findings, it can be hypothesized that the higher diversity of the ecological niches has favored the small carnivores, thanks also to a high number of small-sized prey.

The analyses of the values of the first and last occurrences, together with the faunal renewals in the intervals between the several Faunal Units and the Mammal Ages (Fig. 6), allows a comparison to be done in respect to the turnover line and the quantity of recorded mammal taxa (Fig. 9A). The relative turnover lines (continuous line) in all of the peninsula and the abundance of taxa line in the same temporal interval (dashed line) relate in some way: even in Figure 9B, which summarizes the relative data of the taxa and of the turnover in Central Italy, it is possible to observe the same trend: maximum values of the abundance of taxa correspond to the minimum values of the turnover, even if in an approximate way; this can signify, therefore, that in moments of rich biodiversity there is a low faunal renewal and vice versa.

The relative abundance of brachydonts, mesodonts and hypsodonts is related to a progressive reduction of the wooded areas. From the Pliocene to the Holocene the wooded areas started to thin out into clearings and prairies; this phenomenon is more evident in the last one million year (Fig. 7).

To explain how the abundance of mammals, indicative of open lands, can compare with the prevalence of humid forests in the paleobotanical record, it is necessary to hypothesize that the population of grazing mammals (which increased in numbers during the steppic phases) could have wielded - during the more humid, climatic phases an impact on the vegetation, impeding the growth of arboreal plants on fairly widespread areas and favoring the growth of herbaceous plants.

The great faunal renewals, which correspond, as stated before, to the passage between the Villafranchian, the Galerian and the Aurelian do not seem to have been caused only by strong climatic turnovers; nevertheless, these changes, together with strong floral changes, could have had a significant role in the distribution and then in the diffusion of the many ecological niches. An interesting issue that asks for further in-depth examination is represented by the turnover lines that seem to coincide (Figs 1; 9) with the principal moments of paleomagnetic inversion of the Pliocene-Pleistocene (the passage Gauss-Matuyama, the subchrons Olduvai and Jaramillo).

At the moment it can possibly be asserted that the principal changes of biodiversity during the Pliocene and Pleistocene were caused by all of these factors; to these, for the last part of the Pleistocene, the influence of human activities, by Homo neanderthalensis (King, 1864) first and then by Homo sapiens Linnaeus, 1758 later, could have directly or indirectly had an influence on the ecosystems.

\section{Aknowledgements}

This work has been supported by MIUR PRIN 2006 grants (resp. C. Petronio).

\section{REFERENCES}

Acanfora M. O. 1962. - Gli scavi di Valle Ottara presso Cittaducale. Bollettino Paletnologia Italiana 71/72: 101-154.

Alhaique F. 1996. - Sfruttamento dei piccoli mammiferi e dei carnivori nel Paleolitico superiore di Grotta Polesini, in Peretto C. \& Milliken S. (eds), L'adattamento umano all'ambiente, passato e presente. Atti XI congresso degli Antropologi Italiani. Abaco, Forlì: 209, 210.

Alhaique F., Biondi S., Cassoli P. F., Recchi A. \& TAGLIACOZZO A. 1988. - Modifications in the exploitation of animal resources between the Middle Palaeolithic and the Aurignacian at Grotta del Fossellone (Monte Circeo, Italy). Atti UISPP XIII 6 (1): 571-576. 
Alhaique F., Bietti A., Capasso Barbato L., GrimalDi S., KotSAKIS T., KuHn S., LemOrini C., MANZI G., ReCCHI A., SCHWARCHZ H. P. \& STINER M. 1998. Settlement patterns and subsistence strategies in the la mousterian site of Grotta Breuil (Mt. Circeo, Italy). Atti UISPP XIII 6 (1): 221-228.

Arzarello M., Belardinelli l., Minelli A., PaVia M., Rufo E., Sala B., Thun Hohenstein U. \& Peretto C. 2004. - Il sito paleolitico medio di Grotta Reali (Rocchetta del Volturno, Molise, Italia). Rivista Scienze Preistoriche 54: 249-269.

Arzarello M., Marcolini F., Pavia G., Pavia M., Petronio C., Petrucci M., Rook L. \& Sardella R. 2007. - Evidence of earliest human occurrence in Europe: the site of Pirro Nord (Southern Italy). Naturwissenschaften 94 (2): 107-112.

AZZAROLI A. 1977. — The Villafranchian stage in Italy and the Plio-Pleistocene boundary. Giornale di Geologia 41: 61-79.

Benvenuti M., Bertini A., Conti C. \& Dominici S. 2007. - Integrated analyses of litho- and biofacies in a Pliocene cyclothemic, alluvial to shallow marine succession (Tuscany, Italy). Geobios 40: 143-158.

BERTINI A. 2000. — Pollen record from Colle Curti and Cesi: Early and Middle Pliestocene mammal sites in the Umbro-Marchean Apennine Mountains (central Italy). Journal Quaternary Sciences 15 (8): 825-840.

BERTINI A. 2006. - The Northern Apennines palynological record as a contribute for the reconstruction of the Messinian palaeoenvironments. Sedimentary Geology 188/189: 235-258.

BiANUCCI G. P. 1980. — Ricerche speleologiche alla Buca dei Ladri (Asciano-Pisa). Atti Società Toscana di Scienze Naturali Memorie S.A 87: 261-274.

BieTTI A. 1984. - Primi risultati dello scavo nel giacimento epigravettiano finale di Riparo Salvini (Terracina, Latina). Atti IIPP XXIV: 195-205.

Billia M. E. \& Petronio C. 2009. - Selected records of Stephanorhinus kirchbergensis (Jäger, 1839) (Mammalia, Rhinocerotidae) in Italy. Bollettino della Società Paleontologica Italiana 48 (1): 21-32.

Bologna P., Di Stefano G., Manzi G., Petronio C., Sardella R. \& SQuazzini E. 1994. — Late Pleistocene mammals from a the Melpignano (LE) "Ventarole": preliminary analysis and correlations. Bollettino della Società Paleontologica Italiana 33 (2): 263-274.

Boscato P. 1996. — Vado all'Arancio (Massa Marittima, GR). Studio delle faune. Rassegna di Archeologia 13: 159-176.

Boscato P., Cattani L., Cuda M. T. \& Martini F. 2001. - Il Musteriano della grotta di S.Francesco a Belverde di Cetona. Rivista Scienze Preistoriche 51:3-48.

Bulgarelli G. M. \& Tagliacozzo A. 1984. - Il paleolitico superiore di Ponte Sfondato (Montopoli Sabina). Atti IIPP XXIV: 175-181.
Caloi L. \& Palombo M. R. 1987. — I grandi mammiferi del Pleistocene superiore di Grotta Barbara (Monte Circeo, Lazio meridionale). Bollettino Servizio Geologico d'Italia 106: 3-58.

Caloi L., Palombo M. R. \& Petronio C. 1979. Cenni preliminari sulla fauna di Cava Redicicoli (Roma). Bollettino Servizio Geologico d'Italia 100: 189-198.

Caloi L., Palombo M. R. \& Petronio C. 1980. La fauna quaternaria di Sedia del Diavolo (Roma). Quaternaria 22: 177-209.

Caloi L., Coccolini G. B. L., Mussi M., Palombo M. R., Vitagliano S. \& Zampetti D. 1989. - Le Moustérien du Latium (Italie centrale) : archéologie milieu naturel, chronologie. L'Anthropologie 93 (1): 73-98.

Capasso Barbato L., Cuggiani M. C. \& Petronio C. 1982. - I macromammiferi del Pleistocene superiore della grotta di Monte Cucco (Sigillo, Perugia). Bollettino Servizio Geologico d'Italia 103: 105-132.

Capasso Barbato L., Di Stefano G., Petronio C. \& SARDELla R. 1998. - Pleistocene mammal faunas from Ponte Molle (Rome). Quaternary International 47/48: 73-75.

Capasso Barbato L., Minieri M. R. \& Scarano M. 1991. - Paleogeografia dei mammiferi "freddi" del Pleistocene medio-superiore e superiore italiano. Atti Accademia Peloritana dei Pericolanti 67 supplemento 1: 231-259.

Capraro L., Asioli A., Bertoldi R., Channell J. E. T., MASSARI F. \& Rio D. 2005. - Climatic patterns revealed by pollen and oxygen isotope records across the Matuyama-Brunhes boundary in the central Mediterranean (southern Italy). Geological Society Special Publications 247: 159-182.

Cassoli P. F. 1976. — Upper Palaeolithic fauna at Palidoro (Rome): 1955 excavations. Quaternaria 19: 187-196.

Castelletti L., Maspero A. \& Tozzi C. 1994. - Il popolamento della Valle del Serchio (Toscana settentrionale) durante il Tardiglaciale würmiano el'Olocene antico, in Biagi P. \& Nandris J. (eds), Highland zone exploitation in southern Europe. Monografie di Natura Bresciana 20: 189-204.

Cavallo P. \& Martinetto E. 2001. - Flore carpologiche del Pliocene di Castelletto Cervo (Biella). Bollettino del Museo Regionale di Scienze Naturali di Torino 18 (2): 277-343.

Cazzella A. \& Moscoloni M. 1984. - Tracce di insediamento del Paleolitico superiore a Tor Vergata (Roma). Atti IIPP XXIV: 165-173.

Cerilli E. \& Brocato G. 1998. - The Upper Palaeolithic deposit of Valle Arcione (Castel d'Asso, Viterbo, Italy). Atti UISPP XIII 2: 681-685.

Cilli C., Malerba G. \& Tozzi C. 1998. — Analyse archéozoologique et modifications de surface des restes fauniques de deux sites du Paléolithique supérieur de 
Toscane (Italie). Atti UISPP XIII 2: 675-679.

Coltorti M., Feraud G., Marzoli A., Peretto C., Ton-That T., Voinchet P., Bahain J.-J., Minelli A. \& Thun Hohenstein U. 2005. - New 40Ar/39Ar, stratigraphic and palaeoclimatic data on the Isernia La Pineta Lower Palaeolithic site, Molise, Italy. Quaternary International 131: 11-22.

Cremonesi G. 1968. - Contributo alla conoscenza della preistoria del Fucino: la Grotta di Ortucchio e la Grotta La Punta. Rivista Scienze Preistoriche 23: 145-204.

Del Campana D. 1954. - Carnivori quaternari della Tecchia e della Caverna di Equi nelle Alpi Apuane (Mustelidi, Canidi, Felidi). Palaeontographia italica 44 (2): 1-42.

Di Canzio E. \& Petronio C. 2001. - Osservazioni sulla fauna a vertebrati pleistocenici della Grotta Cola (Abruzzo, Aquila). Bollettino della Società Paleontologica Italiana 40 (1): 105-114.

Di Canzio E., Bedetti C., Petronio C. \& Sardella R. 2003. - Middle Pleistocene vertebrate fauna from Cretone (Sabina, Latium). Bollettino della Società Paleontologica Italiana 42: 129-132.

Di Stefano G. \& Petronio C. 2000. — Systematics and evolution of the Eurasian Plio-Pleistocene tribe Cervini (Artiodactyla, Mammalia). Geologica Romana 36: 311-334.

FABIANI R. 1922. - La fauna mammalogica della "Buca del Tasso". Archivio per l'Antropologia e l'Etnologia 52: 10-20.

Favre E., François L., Fluteau F., Cheddadi R., TheVENOD L. \& SUC J.-P. 2007. — Messinian vegetation maps of the Mediterranean region using models and interpolated pollen data. Geobios 40 (3): 433-443.

Follieri M., MAGRI D. \& SADORI L. 1988. — 250000 year pollen record from Valle di Castiglione (Roma). Pollen et Spores 30 (3, 4): 329-356.

Girotti O., Capasso Barbato L., Esu D., Gliozzi E., Kotsakis A., Martinetto E., Petronio C., Sardella R. \& SQuazzini E. 2003. - The section of Torre Picchio (Terni, Umbria, Central Italy): A Villafranchian site rich in Mammals, Molluscs, Ostracods and Plants. Rivista Italiana di Paleontologia e Stratigrafia 109 (1): 77-98.

GIUSTIZIA F. 1979. - Il deposito musteriano nel Riparo I Grottini presso Balascio (L'Aquila). Nota preliminare. Atti Società Toscana di Scienze Naturali Memorie S.A 86: 189-201.

Gliozzi E., Abbazzi L., Argenti P., Azzaroli A., Caloi L., Capasso Barbato L., Di Stefano G., Esu D., Ficcarelli G., Girotti O., Kotsakis T., Masini F., Mazza P., Mezzabotta C., Palombo M. R., Petronio C., Rook L., Sala B., Sardella R., ZANALDA E. \& Torre D. 1997. — Biochronology of selected Mammals, Molluscs and Ostracods from the Middle Pliocene to the Late Pleistocene in Italy.
The state of the art. Rivista Italiana di Paleontologia e Stratigrafia 103: 369-388.

Graziosi P. 1928. - La Grotta di Talamone. Archivio per l'Antropologia e l'Etnologia 58: 122-152.

GrAZIOSI P. 1944. — La Grotta all'Onda secondo gli scavi dell'Istituto Italiano di Paleontologia Umana (1931). Archivio per l'Antropologia e l'Etnologia 64: $73-120$

Grifoni R. \& Radmilli A. M. 1964. - La Grotta Maritza e il Fucino prima dell'età romana. Rivista Scienze Preistoriche 19: 53-127.

Guérin C., Faure M., Argant A., Argant J., CregutBonnoure E., Debard E., Delson E., Eisenmann V., Hugueney M., Limondin-Lozouet N., MartinSuarez E., Mein P., Mourer-Chauviré C., Parenti F., Pastre J.-F., Sen S. \& Valli A. M. F. 2004. - Le gisement pliocène supérieur de Saint-Vallier (Drôme, France): synthèse biostratigraphique et paléoécologique, in Faure M. \& Guérin C. (eds), Le gisement pliocène final de Siant-Vallier (Drôme, France). Geobios 37 (mémoire spécial 26): 349-360.

Guerreschi A., Silvestrini M., Peresani M., Esu D., Gallini V., Magnatti M. \& Muratori S. 2005. - I depositi epigravettiani del sito 1 di Cava Romita: cronologia, faune, industria litica. Atti IIPP XXXVIII: 117-130.

Kotsakis T., Abbazzi L., Angelone C., Argenti P., Barisone G., Fanfani F., Marcolini F. \& Masini F. 2003. - Plio-Pleistocene biogeography of Italian mainland micromammals, in Reumer J. W. F. \& Wessels W. (eds), Distribution and migration of Tertiary mammals in Eurasia. A volume in honour of Hans de Brujin. Deinsea 10: 313-342.

Kotsakis T., Petronio C., Angelone C., Bellucci L., Marcolini F., Salari L. \& Sardella R. 2008. Changes in the Late Villafranchian Mammal assemblages (from Farneta to Pirro FU, Early Pleistocene) of Italy. Abstract 33rd International Geological Congress, Oslo 6-14 august 2008.

Leroy S. A. G. 2007. - Progress in palynology of the Gelasian-Calabrian Stages in Europe: ten messages. Revue de Micropaléontologie 50: 293-308.

LiNDSAY E. H., OPDYKE N. D. \& JOHNSON N. M. 1980. Pliocene dispersal of the horse Equus and late Cenozoic mammal dispersal events. Nature 287: 135-138.

Lona F. \& BerToldi R. 1973. — La storia del PlioPleistocene italiano in alcune sequenze vegetazionali lacustri e marine. Atti dell'Accademia Nazionale dei Lincei Memorie serie 8, 11 (1): 1-47.

MaI D. H. 1994. — Fossile Koniferenreste in der meridionalen Zone Europas. Feddes Repertorium, 105 $(3,4):$ 207-227.

MaI D. H. 1995. - Tertiäre Vegetationsgeschichte Europas. Gustav Fischer, Jena, 691 p.

MARTinetTo E. 1996. - Pliocene vegetation at the western margin of the Po Basin. Allionia 34: 349-355. 
MartinetTo E. 1999. - Chronological framing of Pliocene to Early Pleistocene plant macrofossil assemblages from northern Italy. Acta Palaeobotanica Suppl. 2: 503-511.

MartinetTo E. 2001. - Studies on some exotic elements of the Pliocene floras of Italy. Palaeontographica, Abt. B, 259: 149-166.

MartinetTo E. \& Mai D. H. 1996. — Macrofossili vegetali, in Carraro F. (ed.), Revisione del Villafranchiano nell'area-tipo di Villafranca d'Asti. Il Quaternario 9 (1): 73-79.

MartinetTo E., Scardia G. \& Varrone D. 2007. Magnetobiostratigraphy of the Stura di Lanzo Fossil Forest succession (Piedmont, Italy). Rivista Italiana di Paleontologia e Stratigrafia 113 (1): 109-125.

Mazza P. A., Bertini A. \& Magi M. 2004. — The late Pliocene site of Poggio Rosso (central Italy); taphonomy and paleoenvironment. Palaios 19 (3): 227-248.

Mazzini I., Paccara P., Petronio C. \& Sardella R. 2000. - Geological Evolution and Biochronological Evidence of the Monte Riccio Section. Rivista Italiana di Paleontologia e Stratigrafia 106 (2): 247-256.

Merril R. T., McElhinny M. W. \& McFadden P. L. 1996. - The Magnetic Field of the Earth: Paleomagnetism, the Core and the Deep Mantle. San Diego Academic Press, San Diego, 541 p.

Monegatti P., CANali G., Bertoldi R. \& Albianelli A. 2002. - The classical Late Piacenzian Monte FalconeRio Crevalese section (Northern Italy): palynological evidence and biomagnetostratigraphic constraints for climatic cyclicity and local mollusc extinctions. Geobios (mémoire spécial 24): 219-227.

Napoleone G., AzZaroli A. \& Mazzini M. 2003. Magnetochronologic significant of the end-pliocene age of the new found locality of Poggio Rosso in the Upper Valdarno, for dating its late Villafranchian faunas. Rivista Italiana di Paleontologia e Stratigrafia 107 (2): 287-296.

Palmarelli A. \& Palombo M. R. 1981. - Un cranio di Coelodonta antiquitatis (Blumenbach) (Rhinocerotidae) del Pleistocene superiore del Monte Circeo (Lazio meridionale). Bollettino Servizio Geologico d'Italia 102: 281-312.

Palombo M. R. \& Ferretti M. P. 2005. — Elephant fossil record from Italy: knowledge, problems, and perspectives. Quaternary International 126-128: 107136.

Palombo M. R., Azanza B. \& Alberdi M. T. 2002. Italian mammal biochronology from the Latest Miocene to the Middle Pleistocene: a multivariate approach. Geologica Romana 36: 335-368.

PeTRONIO C. 1995. - Note on the taxonomy of Pleistocene Hippopotamuses. IBEX Journal of Mountain Ecology 3: 53-55.

Petronio C. \& Sardella R. 1999. - Biochronology of the Pleistocene mammal fauna from Ponte Ga- leria (Rome) and remarks on the Middle Galerian faunas. Rivista Italiana di Paleontologia e Stratigrafia 105: 155-164.

Petronio C., Argenti P., Caloi L., Esu D., Girotti O. \& SARDELla R. 2002. - Updating Villafranchian mollusc and mammal faunas of Umbria and Latium (Central Italy). Geologica Romana 36: 369-387.

Petronio C., Anzidei A. P., Bedetti C., Bona F., Di Canzio E., Gentili S., Mazza P., Palombo M. R., Pavia M., Salari L., Sardella R. \& Tintori A. 2005. - Le faune a mammiferi del Plio-Pleistocene, in Bonfiglio L. (ed.), Paleontologia dei Vertebrati in Italia. Memorie Museo Civico Storia Naturale di Verona, II S., Scienze della Terra 6: 183-218.

Petronio C., Di Canzio E. \& Salari L. 2007. - The Late Pleistocene and Holocene Mammals in Italy: new biochronological and paleoenvironmental data. Palaeontographica, Abt. A, 279: 147-157.

PitTi C., Sorrentino C. \& Tozzi C. 1976. - L'industria di tipo paleolitico superiore arcaico della Grotta La Fabbrica (Grosseto). Nota preliminare. Atti Società Toscana di Scienze Naturali Memorie S.A 83: 174-201.

PitTi C. \& Tozzi C. 1971. — La Grotta del Capriolo e la Buca della Iena presso Mommio (Camaiore, Lucca). Rivista Scienze Preistoriche 26: 213-258.

Pontini M. R. \& Bertini A. 2000. — Late Pliocene vegetation and climate in central Italy: high-resolution pollen analysis from the Fosso Bianco succession (Tiberino Basin). Geobios 33: 519-526.

RADI G. 1982. - L'industria Bertoniana del riparo di Venere (L'Aquila). Atti Società Toscana di Scienze Naturali 89: 189-207.

Radmilli A. M. 1977. - Storia dell'Abruzzo dalle origini all'età del bronzo. Collana Studi Paletnologici, Giardini, Pisa, 464 p.

Radmilli A. M., Romagnoli L. \& Tongiorgi E. 1955. - Il deposito eolico sul versante occidentale del promontorio di Ansedonia e la fauna fossile della grotta Rose Mary. Atti Società Toscana di Scienze Naturali 62: 73-87.

RaVAZZI C. 2002. — Late Quaternary history of spruce in Southern Europe. Review of Palaeobotany and Palynology 120 (1, 2): 131-177.

Ravazzi C., Pini R., Breda M., Martinetto E., Muttoni G., Chiesa S., Confortini F. \& Egli R. 2005. - The lacustrine deposits of Fornaci di Ranica (late Early Pleistocene, Italian Pre-Alps): stratigraphy, palaeoenvironment and geological evolution. Quaternary International 131: 35-58.

RoOK L. \& SARDELla R. 2005. - Hystrix refossa Gervais, 1852 from Pirro Nord (Early Pleistocene, Southern Italy). Rivista Italiana Paleontologia e Stratigrafia 111: 489-496.

Rook L., Martínez-Navarro B. \& Howell F. C. 2004. - Occurrence of Theropithecus sp. in the Late 
Villafranchian of Southern Italy and implication forEarly Pleistocene "out of Africa" dispersals. Journal of Human Evolution 47: 267-277.

RUFFo M. 1995. - Origine degli insiemi faunistici nei vari livelli deposizionali della Grotta delle Capre S.Felice Circeo (LT) - 1993. Atti $1^{\circ}$ Conv. Naz. Archeozoologia, Padusa Quaderni 1: 109-123.

Russo ERmolir E. 2000. - Pollen analysis of the Acerno palaeo-lacustrine succession (middle Pleistocene, southern Italy). Geological Society Special Publications 181: 151-159.

Russo Ermolli E., Juvigné É., Bernasconi S., BranCACCio L., Cinque A., Lirer L., Ozer A. \& SANTANGELO N. 1995. - Le premier stratotype continental de quatre stades isotopiques successifs du Pléistocène moyen pour le bassin méditerranéen septentrional: le Vallo di Diano (Campanie, Italie). Comptes Rendus de l'Académie des Sciences de Paris 321 (2a): 877-884.

Rustioni M., Mazza P. \& Balestri M. 1999. - The Middle-Late Pleistocene mammal fauna from Montignoso (Leghorn, Central Italy). Il Quaternario 12 (1): 105-111.

Sardella R., Abbazzi L., Argenti P., Azzaroli A., Caloi L., Capasso Barbato L., Di Stefano G., Ficcarelli G., Gliozzi E., Kotsakis T., Masini F., Mazza P., Mezzabotta C., Palombo M. R., Petronio C., Rook L., Sala B. \& Torre D. 1998. - Mammal Faunal Turnover in Italy from the Middle Pliocene to the Holocene. Mededelingen Nederlands Instituut voor Toegepaste Geowetenschappen TNO 60: 499-512.

Segre A. G. \& AsCenZi A. 1956. — Giacimenti del paleolitico superiore e del bronzo nei travertini di Cisterna (Latina). Rivista di Antropologia 43: 367-411.

Segre A. G., Biddittu I. \& Cassoli P. F. 1984. Il bacino paleolacustre di Sora (Frosinone) e i suoi giacimenti musteriani. Atti IIPP XXIV: 149-154.

Segre Naldini E. 1984. - Il Musteriano di Grotta della Cava, Sezze Romano (Latina). Atti IIPP XXIV: 141-147.

SHAKRYL A. K. 1990. — Development of Lauraceae in the Colchidian refuges, in Knobloch E. \& KvaČek Z. (eds), Proceedings of the Symposium Palaeofloristic and Palaeoclimatologic Changes in the Cretaceous and Tertiary. Geological Survey Publisher, Prague: 311-313.

Sommer R. \& BeneCKe N. 2004. - Late- and postglacial history of the Mustelidae in Europe. Mammal Review 34 (4): 249-284.

Suc J.-P. \& Bessais E. 1990. — Pérennité d'un climat thermoxérique en Sicile, avant, pendant et après la crise de salinité messinienne. Comptes Rendus de l'Académie des Sciences de Paris 310 (II): 1701-1707.

SuC J.-P. \& POPESCU S.-M. 2005. — Pollen records and climatic cycles in the north Mediterranean region since 2.7 Ma. Geological Society Special Publications 247: 147-158.

Suc J.-P., Bertini A., Combourieu-Nebout N., DiNiZ F., Leroy S., Russo-Ermolli E., Zheng Z., Bessais E. \& FERrier J. 1995a. - Structure of West Mediterranean and climate since 5.3 Ma. Acta Zoologica Cracoviensia 38 (1): 3-16.

Suc J.-P., Diniz F., Leroy S., Poumot C., Bertini A., Dupont L., Clet M., Bessais E., Zheng Z., FAUQuetTE S. \& FERRIER J. 1995b. — Zanclean ( Brunssumian) to early Piacenzian ( $\approx$ early-middle Reuverian) climate from $4^{\circ}$ to $54^{\circ}$ north latitude (West Africa, West Europe and West Mediterranean areas). Mededelingen Rijks Geologische Dienst 52: 43-56.

SutCliffe A. 1964. - The mammalian fauna, in Ovey C. D. (ed.), The Swanscombe skull. Royal Anthropological Institute Occasioned Papers 20: 85-111.

TozZI C. 1970. — La Grotta di S.Agostino (Gaeta). Rivista Scienze Preistoriche 25: 3-87.

Tozzi C. 1974. - L'industria musteriana della Grotta di Gosto sulla Montagna di Cetona. Rivista Scienze Preistoriche 29: 271-304.

Vitagliano S. 1984. - Nota sul Pontiniano della Grotta dei Moscerini, Gaeta (Latina). Atti IIPP XXIV: 155-164.

WilKens B. 1991. - Resti faunistici ed economia preistorica nel bacino del Fucino. Atti del convegno di archeologica "Il Fucino e le aree limitrofe nell'antichità". Archeoclub d'Italia, Marsica: 147-153. 


\section{APPENDICES}

TABLE 1. - Early and Middle Villafranchian mammal faunas from selected localities in Central Italy. $\times$, local record of each taxon; *, total of local records for each taxon. Abbreviations: EV, early Villafranchian; MV, middle Villafranchian; CSG, Coste San Giacomo; Mon, Montopoli; Tri, Triversa.

Localities Mammal Ages

Faunal Units

Anancus arvernensis Mammut borsoni

Tapirus arvernensis Homotherium latidens Mammuthus gromovi Stephanorhinus janvireti Lynx issiodorensis Stephanorhinus etruscus

Equus livenzovensis

Axis lyra

Croizetoceros ramosus

Eucladoceros falconeri

Gazella borbonica

Leptobos stenometopon

Acinonyx pardinensis

Nyctereutes megamastoides

Pliocrocuta perrieri

Sus minor

Hemitragus sp.

Megantereon cultridens

Mammuthus meridionalis meridionalis

Eucladoceros teguliensis

Equus stenonis

Gazellospira torticornis

Leptobos merlai furtivus

Gallogoral meneghini

Canis etruscus

Vulpes alopecoides

Procapreolus sp.

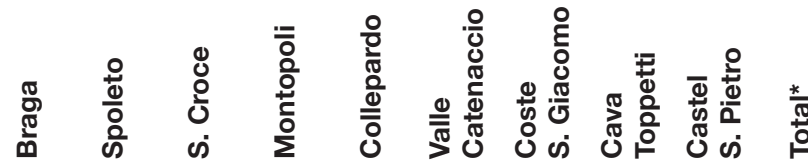

\section{EV}

MV

Tri Mon CSG

$\times \quad \times$

$\times \quad \times \quad 5$

$x$

$\times \quad \times$

$\times$

$\times$

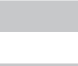

$x$

\begin{tabular}{|c|c|}
\hline$\times$ & \\
\hline$\times$ & $\times$ \\
\hline
\end{tabular}

$\times$
$\times$

$\begin{array}{llll}\times & \times & \times & \times \\ \times & \times & & 2 \\ \times & \times & \end{array}$

$\times \times \times \times 5$

$\begin{array}{lll}x & x & x \\ x & 1\end{array}$

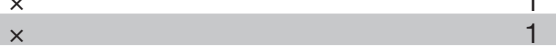

$\begin{array}{lll}x & \times\end{array}$

$\begin{array}{lll}x & x & 1\end{array}$

$\begin{array}{ll}x & 1\end{array}$

$x \quad \times \quad 2$

$\times \quad \times \quad 2$

$\begin{array}{lll}x & x & 2 \\ x & 1\end{array}$

$\times$
$\times$

$\times 1$

$\begin{array}{ll}x & x \\ x & 2\end{array}$

\begin{tabular}{|c|c|c|c|}
\hline$x$ & & & $?$ \\
\hline$\times$ & & & 1 \\
\hline$\times$ & & & 1 \\
\hline$\times$ & $x$ & $x$ & 3 \\
\hline$\times$ & & & 1 \\
\hline$\times$ & & & 1 \\
\hline$\times$ & & & 1 \\
\hline & $\times$ & & 1 \\
\hline
\end{tabular}

Total

$2 \quad 3$

136

5

5


TABLE 2. - Late Villafranchian mammal faunas from selected localities in Central Italy. $\mathbf{x}$, local record of each taxon; *, total of local records for each taxon. Abbreviations: LV, late Villafranchian; Far, Farneta; Oli, Olivola; Pir, Pirro; Tas, Tasso.

\begin{tabular}{|c|c|c|c|c|c|c|c|c|c|c|c|c|c|c|c|c|c|c|c|c|c|c|}
\hline Localities & 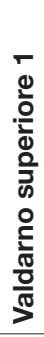 & $\frac{\pi}{0}$ & 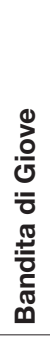 & & 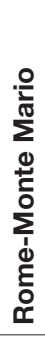 & 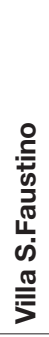 & $\begin{array}{l} \\
\frac{0}{\frac{1}{0}} \\
\frac{0}{\alpha} \\
\stackrel{0}{0} \\
\stackrel{ }{0}\end{array}$ & 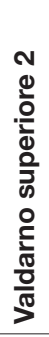 & 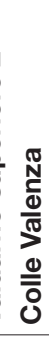 & 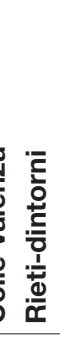 & 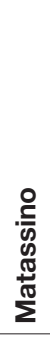 & 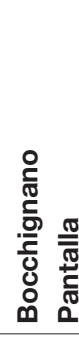 & 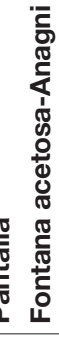 & 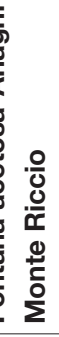 & 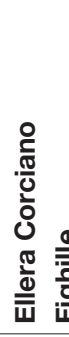 & 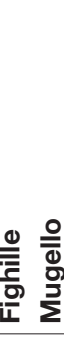 & 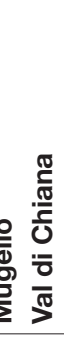 & $\frac{\pi}{\frac{\pi}{\pi}}$ & 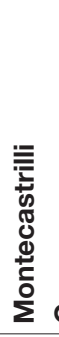 & 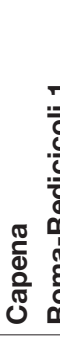 & 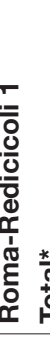 & $\begin{array}{l}\frac{\pi}{\pi} \\
\frac{*}{0} \\
\end{array}$ \\
\hline Mammal Age & & & & & & & & & & & & LV & & & & & & & & & & \\
\hline Faunal Units & & & & Oli & & & & & & & & Tas & & & & & & ar & & Pir & & \\
\hline Mammuthus meridionalis meridionalis & $x$ & $x$ & $x$ & & $x$ & & $x$ & $x$ & $x$ & $x$ & $x$ & & $x$ & $x$ & & & & & & & & 11 \\
\hline Stephanorhinus etruscus & $x$ & $x$ & $x$ & $x$ & & $x$ & $x$ & $x$ & $x$ & & & & & $x$ & $x$ & & & & & & & 11 \\
\hline Equus stenonis & $x$ & $x$ & & $x$ & & $x$ & $x$ & $x$ & & $x$ & $x$ & $\times \times$ & $x$ & $x$ & & & & & & & & 12 \\
\hline Axis nestii & $x$ & $x$ & & & & $x$ & $x$ & $x$ & & & $x$ & $x$ & $x$ & $x$ & $x$ & & & & & & & 10 \\
\hline Sus strozzii & $x$ & $x$ & & & & $x$ & $x$ & $x$ & & & $x$ & $x$ & $x$ & $x$ & & $x$ & $x$ & & & & & 11 \\
\hline Procamptoceras brivatense & $x$ & $x$ & & & & & & & & & & & & & & & & & & & & 2 \\
\hline Procapreolus sp. & & & & & & & & & & & & & & $x$ & & & & & & & & 1 \\
\hline Eucladoceros dicranios & $x$ & $x$ & & & & & & & & & & & $x$ & & & & & & & & & 3 \\
\hline Leptobos etruscus & $x$ & $x$ & & & & & & $x$ & & & $x$ & & & $x$ & & & $x$ & & & & & 6 \\
\hline Leptobos merlai-furtivus & $x$ & $x$ & & & & & & & & & & & & & & & & & & & & 2 \\
\hline Gallogoral meneghini & $x$ & $x$ & & & & & & & & & & & & & & & & & & & & 2 \\
\hline Canis etruscus & $x$ & $x$ & & & & & & & & & $x$ & $x$ & $x$ & $x$ & & & $x$ & & & & & 7 \\
\hline Vulpes alopecoides & & & & & & & & & & & & & & $x$ & & & & & & & & 1 \\
\hline Ursus etruscus & $x$ & $x$ & & & & & & $x$ & & & & & $x$ & & & $x$ & $x$ & $x$ & & & & 7 \\
\hline Homotherium latidens & $x$ & $x$ & & & & & $x$ & $x$ & & & & & & & & & $x$ & & & & & 5 \\
\hline Lynx issiodorensis & $x$ & $x$ & & & & & & $x$ & & & & $x$ & & & & & & & & & & 4 \\
\hline Megantereon cultridens & $x$ & $x$ & & & & $x$ & & $x$ & & & & & $x$ & $x$ & & & & & & & & 6 \\
\hline Pachycrocuta brevirostris & $x$ & $x$ & & & & $x$ & & $x$ & & & & & $x$ & & & & & & & & & 5 \\
\hline Enhydrictis ardea & & $x$ & & & & & & & & & & & & & & & & & & & & 1 \\
\hline Chasmaportetes lunensis & & $x$ & & & & & & & & & & & & & & & & & & & & 1 \\
\hline Felis Iunensis & & $x$ & & & & & & & & & & & & & & & & & & & & 1 \\
\hline Panthera gombaszoegensis & & $x$ & & & & & & $x$ & & & & $x$ & & & $x$ & & & $x$ & & & & 5 \\
\hline Leptobos sp. & & & $x$ & & & & & & & & & $x$ & $x$ & & & $x$ & K & & & & & 4 \\
\hline Eucladoceros sp. & & & & $x$ & & $x$ & & & & & & & & & $x$ & & & & & & & 3 \\
\hline Leptobos etruscus vel vallisarni & & & & & & $x$ & $x$ & & & & & & & & & & & & & & & 2 \\
\hline Leptobos vallisarni & & & & & & $x$ & & $x$ & & & & & & & $x \times$ & $x$ & $x$ & $x$ & & & & 6 \\
\hline Eucladoceros dicranios vel ctenoides & & & & & & & $x$ & $x$ & & & $x$ & & & & & $x$ & & & & & & 4 \\
\hline Gallogoral meneghini & & & & & & & $x$ & & & & & & & & & & & & & & & 1 \\
\hline Canis arnensis & & & & & & & $\times$ & $x$ & & & & & $x$ & & & & & & & & & 3 \\
\hline Equus stehlini & & & & & & & & $x$ & & & & & & & & & $x$ & & & & & 2 \\
\hline Hippopotamus antiquus & & & & & & & & $x$ & & & & $x$ & $x$ & $\times$ & $x$ & $x$ & & & $x$ & & & 7 \\
\hline Xenocyon falconeri & & & & & & & & $x$ & & & & & & & & & & & & & & 1 \\
\hline Pannonictis nestii & & & & & & & & $x$ & & & & & & & & & & $x$ & & & & 2 \\
\hline Stephanorhinus sp. & & & & & & & & & & & & & $x$ & & & & & & & & & 1 \\
\hline Eucladoceros ctenoides & & & & & & & & & & & & & & $x$ & & & & & & & & 1 \\
\hline Mammuthus meridionalis vestinus & & & & & & & & & & & & & & & & $x$ & $x$ & $x$ & & & $x$ & 4 \\
\hline Stephanorhinus hundsheimensis & & & & & & & & & & & & & & & & $x$ & s & $x$ & & & & 2 \\
\hline Axis eurygonos & & & & & & & & & & & & & & & & $x$ & $x$ & $x$ & $x$ & $x$ & $x$ & 6 \\
\hline Praemegaceros obscurus & & & & & & & & & & & & & & & & & $x$ & $x$ & & & & 2 \\
\hline Equus sp. & & & & & & & & & & & & & & & & & & $x$ & & & & 1 \\
\hline Equus ex gr. bress.-sussebornensis & & & & & & & & & & & & & & & & & & & $x$ & & & 1 \\
\hline Bison degiulii & & & & & & & & & & & & & & & & & & & & $x$ & $x$ & 2 \\
\hline
\end{tabular}


TABLE 3. - Galerian mammal faunas from selected localities in Central Italy. x, local record of each taxon; *, total of local records for each taxon. Abbreviations: EG, early Galerian; MG, middle Galerian; LG, late Galerian; CC, Colle Curti; FR, Fontana Ranuccio; Ise, Isernia; PG, Ponte Galeria.

Localities

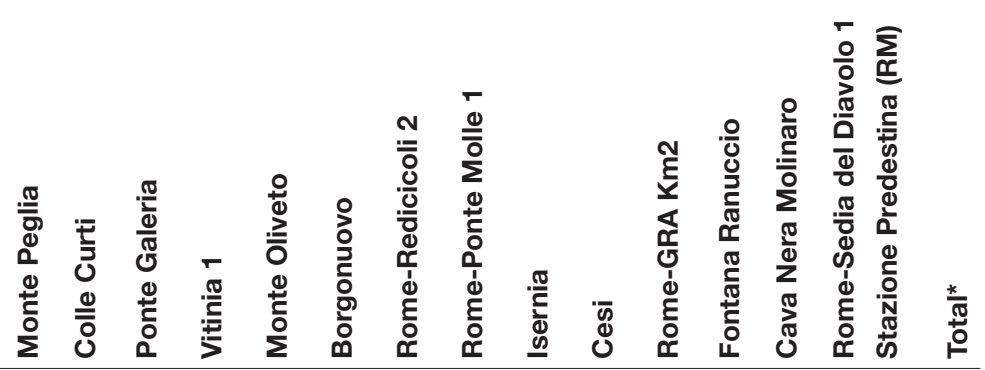

Mammal Ages

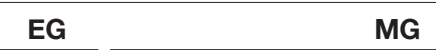

Faunal Units

Axis eurygonos

Xenocyon licanoides

Canis mosbachensis

Homotherium latidens

Ursus sp.

$\frac{\text { EG }}{\times \text { CC }} \frac{\text { PG }}{\times \quad \times \quad \frac{\text { Ise }}{\times \quad \times}} \frac{\text { LG }}{\frac{\text { FR }}{\times}}$

Mammuthus meridionalis vestinus

Stephanorhinus hundsheimensis

Hippopotamus antiquus

Praemegaceros verticornis

Elephas antiquus

Mammuthus trogontherii

Equus altidens

Equus sp.

Megaloceros savini

Cervus elaphus acoronatus

$\times \times \times \times$

$\times \quad \times$

LG

"Bos" galerianus

Praemegaceros solihacus

Bison schoetensacki

Stephanorhinus kirchbergensis

Equus ferus

Sus scrofa

$\times \quad \times$

$\times$

$\times$

FR

Capreolus capreolus

Dama clactoniana

Ursus deningeri

Meles meles

Lyinx ex gr. issiodorensis

Panthera fossilis

$\begin{array}{llll}x & x & 3 \\ x & x & 2\end{array}$

$x \quad x$

$\times$

$\begin{array}{lllllllllllll}\times & \times & \times & & & \times & & \times & \times & 6 \\ \times & \times & & \times & \times & \times & \times & \times & \times & 8\end{array}$

Crocuta crocuta

Hemitragus bonali

Bos sp.

Hyaena prisca

Equus sussenbornensis

$\begin{array}{llllllllll}x & x & \times & \times & x & \times & \times & x & 8 \\ \times & \times & \times & \times & & & & & 4\end{array}$

Hippopotamus amphibius

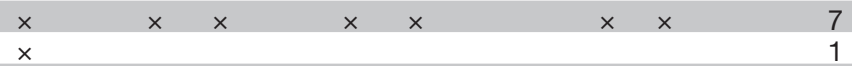

$\begin{array}{rrrr}x & x & x & 1 \\ x & x & 1 \\ x & x & 2\end{array}$

Cervus elaphus eostephanoceros

Bos primigenius

Cuon priscus

Stephanorhinus hemitoechus

$\begin{array}{rrrrrrrrr}\times & \times & & & & 3 \\ \times & \times & \times & & & & \\ \times & & & & & \\ \times & \times & \times & & \times & \times & 7 \\ \times & ? & & & & & & 3\end{array}$

Total

$\begin{array}{lllll}4 & 8 & 11 & 5 & 6\end{array}$

$\times$

$\begin{array}{lll}x & x & x \\ \times & x\end{array}$

3

$\times \quad \times \quad 3$

$\begin{array}{rr}x & 3 \\ \times & 1\end{array}$

$\begin{array}{rr}\times & \times \\ \times & \times\end{array}$

$\begin{array}{llll}x & x & x & 3 \\ x & x & 2\end{array}$

$\times \times \times \times 5$

$\begin{array}{rrrrrr}x & x & x & x & 5 \\ x & \times & & 3\end{array}$

$\begin{array}{lll}x & x & x \\ x & 2\end{array}$

$\begin{array}{rrrr}\times & \times & 2 \\ \times & & 1 \\ \times & ? & 3\end{array}$

$\times$

$\times$

$\times$

\begin{tabular}{rr}
$\times \quad \times$ & 1 \\
$\times \quad \times$ & 2 \\
$\times$ & \\
$\times$ & 1 \\
$\times ?$ & 1 \\
\hline
\end{tabular}

$\begin{array}{llll}11 & 3 & 1 & 1\end{array}$


TABLE 4. - Early and Middle Aurelian mammal faunas from selected localities in Central Italy. $\times$, local record of each taxon; *, total of local records for each taxon. Abbreviations: EA, early Aurelian; MA, middle Aurelian; TP, Torre in Pietra; Vit, Vitinia.

\begin{tabular}{|c|c|c|c|c|c|c|c|c|c|c|c|c|c|c|c|c|c|c|c|c|c|}
\hline Localities & 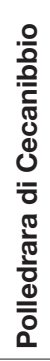 & 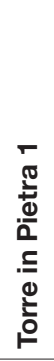 & $\begin{array}{l}\frac{0}{0} \\
\frac{0}{3} \\
0 \\
\frac{1}{0} \\
\frac{0}{0} \\
\frac{1}{80}\end{array}$ & 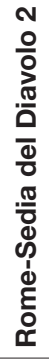 & $\begin{array}{l} \\
\frac{\pi}{ \pm} \\
\frac{\pi}{0} \\
\frac{\pi}{\pi} \\
\end{array}$ & 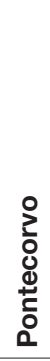 & $\frac{\circ}{\frac{0}{\pi}}$ & $\begin{array}{l}\stackrel{0}{\circ} \\
\stackrel{0}{0} \\
\frac{1}{U}\end{array}$ & 竞 & 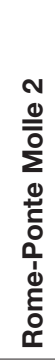 & 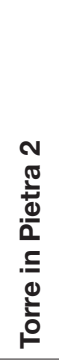 & 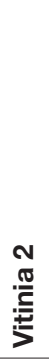 & 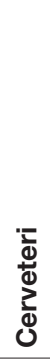 & $\begin{array}{l}\bar{N} \\
\mathbb{D} \\
0 \\
\frac{0}{0} \\
\overline{\mathbb{J}} \\
\mathbb{O}\end{array}$ & 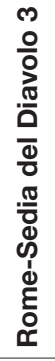 & 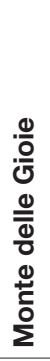 & 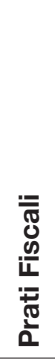 & 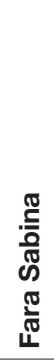 & 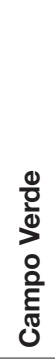 & $\begin{array}{l}\text { 음 } \\
\text { o } \\
\text { 을 } \\
\text { 들 }\end{array}$ & $\frac{*}{\sqrt{\pi}}$ \\
\hline Mammal Ages & \multicolumn{8}{|c|}{ EA } & \multicolumn{13}{|c|}{ MA } \\
\hline Faunal Units & \multicolumn{8}{|c|}{ TP } & \multicolumn{13}{|c|}{ Vit } \\
\hline Elephas antiquus & $x$ & $x$ & $x$ & $x$ & $x$ & $x$ & $x$ & & $x$ & $x$ & $x$ & $x$ & $x$ & $x$ & $x$ & $x$ & $x$ & $x$ & $x$ & $x$ & 19 \\
\hline Stephanorhinus sp. & $x$ & & & & & $x$ & $x$ & & $x$ & & & $x$ & $x$ & $x$ & & & & & & & 7 \\
\hline Stephanorhinus kirchbergensis & & & $\times$ & $x$ & & & & & & & & & & & & & & & & & 2 \\
\hline Equus ferus & $x$ & $x$ & $x$ & & $x$ & $x$ & & & & & $x$ & & $x$ & $x$ & $x$ & & $x$ & $x$ & $x$ & $x$ & 13 \\
\hline Equus sussenbornensis & & & & & & & & & $x$ & & & & & & & & & & & & 1 \\
\hline Cervus elaphus rianensis & $x$ & $x$ & $x$ & & $x$ & $x$ & $x$ & $x$ & $x$ & $x$ & $x$ & $x$ & $x$ & $x$ & $x$ & $x$ & $x$ & $x$ & $x$ & $x$ & 19 \\
\hline Capreolus capreolus & & & & & $x$ & & & & $x$ & $x$ & $x$ & & & $x$ & & & & & $x$ & $x$ & 7 \\
\hline Bos primigenius & $x$ & $x$ & $x$ & $x$ & $x$ & & & & $x$ & $x$ & $x$ & $x$ & $x$ & $x$ & $x$ & $x$ & $x$ & $x$ & & $x$ & 16 \\
\hline Canis lupus & $x$ & $x$ & $x$ & & $x$ & & & & $x$ & $x$ & $x$ & $x$ & & $x$ & $x$ & & & & & $x$ & 11 \\
\hline Crocuta crocuta & & & & & & & & & $x$ & $x$ & $x$ & & & $x$ & & & & & & $x$ & 5 \\
\hline Stephanorhinus hemitoechus & & $x$ & & $x$ & $x$ & & & $x$ & & & $x$ & & & & $\times$ & $x$ & $x$ & $x$ & $x$ & $x$ & 11 \\
\hline Sus scrofa & & $x$ & & & $x$ & $x$ & & & $x$ & $x$ & $x$ & & & $x$ & $x$ & & & $x$ & & $x$ & 10 \\
\hline Megaloceros giganteus & & $x$ & & & & $x$ & & & $x$ & & & & & & & & & & $x$ & & 4 \\
\hline Vulpes vulpes & & $x$ & & & & & & & & & $x$ & $x$ & & & & & & & & $x$ & 4 \\
\hline Ursus spelaeus & & $x$ & & & & & & $x$ & & & & & & & & & & & & & 2 \\
\hline Panthera spelaea & & $x$ & $x$ & & & & & & & & & & & & & & & & & & 2 \\
\hline Hippopotamus amphibius & & & $x$ & & $x$ & $x$ & & & & $x$ & $x$ & & & $x$ & $x$ & $x$ & & & $x$ & $x$ & 10 \\
\hline Canis mosbachensis & & & $x$ & & & & & & & $x$ & & & & $x$ & & & & & $x$ & & 4 \\
\hline Dama clactoniana & & & & $x$ & $x$ & & $x$ & $x$ & & & & & & & & & & & & & 4 \\
\hline Meles meles & & & & $x$ & & & & & & $x$ & $x$ & & & & & & & & & & 3 \\
\hline Bison priscus & & & & & & & & $x$ & $x$ & & & & & & & & & & & $x$ & 2 \\
\hline Canis sp. & & & & & & & & $x$ & & & & & & & & & & & & & 1 \\
\hline Mustela putorius & & & & & & & & $x$ & & & & & & & & & & & & & 1 \\
\hline Felis silvestris & & & & & & & & $x$ & & & & & & & & & & & & $x$ & 2 \\
\hline Mammuthus chosaricus & & & & & & & & & $x$ & & & & & & & & & & $x$ & & 2 \\
\hline Dama dama tiberina & & & & & & & & & $x$ & $x$ & $x$ & $x$ & $x$ & $x$ & $x$ & $x$ & $x$ & $x$ & $x$ & $x$ & 12 \\
\hline Ursus arctos & & & & & & & & & $x$ & & & & & & & & & & & $x$ & 2 \\
\hline Equus hydruntinus & & & & & & & & & & $x$ & & & & & $x$ & & & $x$ & $x$ & & 4 \\
\hline Martes martes & & & & & & & & & & & $x$ & & & & & & & & & & 1 \\
\hline Panthera pardus & & & & & & & & & & & & & & & & & $x$ & & & $x$ & 2 \\
\hline Ursus sp. & & & & & & & & & & & & & & & & & & $x$ & $x$ & & 2 \\
\hline Lynx sp. & & & & & & & & & & & & & & & & & & & & $x$ & 1 \\
\hline Total & 6 & 11 & 9 & 6 & 10 & 7 & 4 & 8 & 14 & 12 & 14 & 7 & 6 & 12 & 10 & 6 & 7 & 9 & 12 & 17 & \\
\hline
\end{tabular}


TABLE 5. - Late Aurelian mammal faunas from selected localities in Central Italy. $\mathbf{x}$, local record of each taxon; *, total of local records for each taxon. Abbreviations: LA, late Aurelian; Mel, Melpignano; Ing, Ingarano.

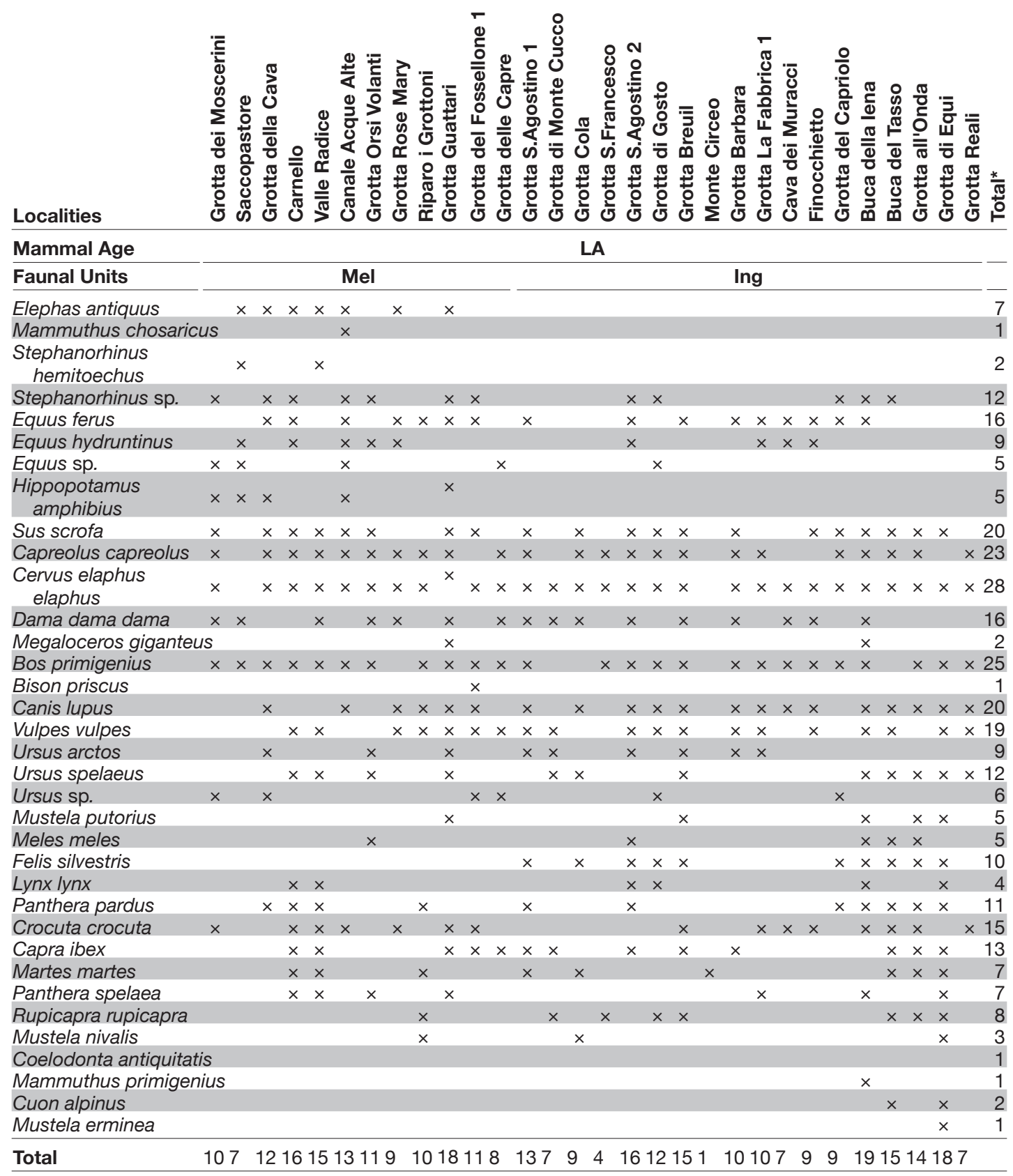


TABLE 6. - Latest Aurelian mammal faunas from selected localities in Central Italy. $\mathbf{x}$, local record of each taxon; *, total of local records for each taxon. Abbreviations: Aur, Aurelian.

\begin{tabular}{|c|c|c|c|c|c|c|c|c|c|c|c|c|c|c|c|c|c|c|c|c|c|c|}
\hline Localities & 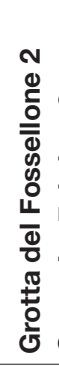 & $\begin{array}{l}\text { N } \\
\frac{0}{0} \\
\frac{0}{2} \\
\frac{0}{\pi} \\
\frac{1}{\pi} \\
\frac{\pi}{3} \\
\frac{\pi}{ \pm} \\
0 \\
0 \\
0\end{array}$ & 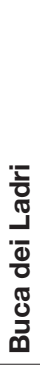 & 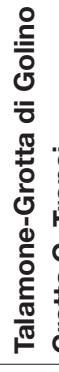 & 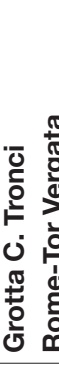 & 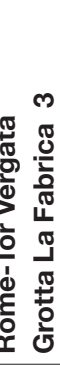 & 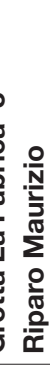 & 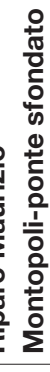 & 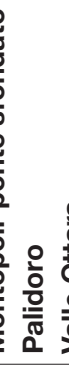 & 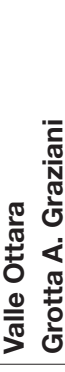 & 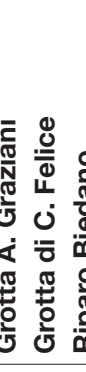 & 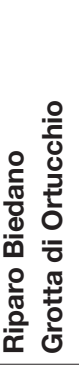 & 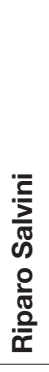 & 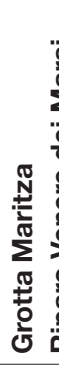 & 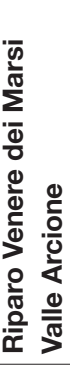 & 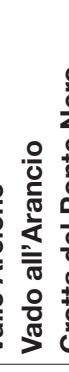 & 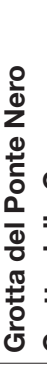 & 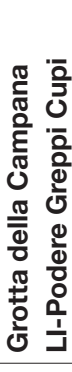 & 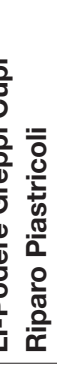 & 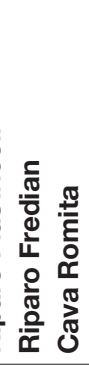 & 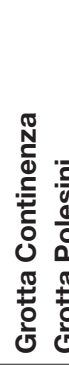 & 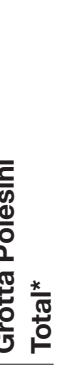 \\
\hline Mammal Age & & & & & & & & & & & & Aur & & & & & & & & & & \\
\hline Isotopic Stage & & & & & & & & & & & & 2 & & & & & & & & & & \\
\hline Equus ferus & $x$ & $x$ & $x$ & & $x$ & $x$ & $x$ & & $x$ & $x$ & $x \times x$ & $x$ & & $x$ & & $x$ & & & & & & $\overline{13}$ \\
\hline Equus hydruntinus & $x$ & $x$ & $x$ & $x>$ & $\times \quad x$ & $x \quad x$ & $x$ & & $x$ & & $x \times$ & $x$ & $x$ & $x$ & $x$ & $x$ & & $x$ & & & $x \times$ & $\times 19$ \\
\hline Sus scrofa & $x$ & & & $x>$ & $x$ & & & & $x$ & & $x$ & $x$ & & $x$ & $x \times$ & $x$ & $x$ & $x$ & $x$ & $x$ & $\times \quad \times$ & $\times 16$ \\
\hline Capreolus capreolus & $x$ & $x$ & $x$ & $x$ & & & $x$ & & $x$ & $x$ & $x$ & & $x$ & $x$ & & $x$ & $x$ & $x$ & $x$ & $\times \times$ & $\times \quad \times$ & $\times 17$ \\
\hline Cervus elaphus elaphus & $x$ & $x$ & $x$ & $\times>$ & $x$ & $x$ & $\times$ & $x$ & $\times>$ & $x \times$ & $x \times$ & $\times \times$ & $x$ & $x$ & $x$ & $x$ & $x$ & $\times \times$ & $x$ & $\times \times$ & $\times \quad \times$ & 27 \\
\hline Dama dama dama & $x$ & $x$ & & & & & & & & & & & & & & & & & & & & 2 \\
\hline Bos primigenius & $x$ & $x$ & $x$ & $x>$ & $\times \quad x$ & $x \quad x$ & $x$ & $x$ & $\times>$ & $\times \quad \times$ & $x \times x$ & $\times \times$ & $x$ & $x$ & $x$ & $x$ & & $\times \times$ & $x$ & $\times$ & $\times \quad \times$ & $\times 26$ \\
\hline Capra ibex & $x$ & & & $x>$ & $\times$ & & & & $x \times$ & $x \times$ & $x \quad x$ & $x$ & $x$ & $x$ & $x$ & & $x$ & $x \times$ & $x$ & $x \times$ & $x \times$ & $\times 19$ \\
\hline Rupicapra rupicapra & $x$ & $x$ & & & & & & & & $x$ & $x \times$ & $x$ & $x$ & $x$ & $x$ & & & $\times$ & $x$ & $\times \times$ & $\times \quad \times$ & $\times 14$ \\
\hline Canis lupus & $x$ & $x$ & & & & & & & $x$ & $x$ & $x \times$ & $x$ & & $x$ & $x$ & $\times \quad \times$ & $x$ & & $x$ & $\times \times$ & $\times \quad \times$ & $\times 15$ \\
\hline Cuon alpinus & & & & & & & & & & & & & & & & & & & & $x$ & & 1 \\
\hline Vulpes vulpes & $x$ & & $x$ & $x$ & & & & & $x$ & $x$ & $x \times$ & $x$ & & $x \times$ & $x$ & & & & & $x$ & $\times x$ & $\times 12$ \\
\hline Ursus arctos & & & & & & & $x$ & & & & & & & & & & & $x$ & $x$ & $x$ & & 4 \\
\hline Ursus sp. & & & & & & & & & & & & & & & & & & & & & & 1 \\
\hline Ursus spelaeus & & & & $x$ & & & & & & & & & & & & & & & & & & 1 \\
\hline Martes martes & & & $x$ & & & & & & & $x$ & x & & & $x$ & & $\times \quad \times$ & $x$ & $x$ & & & $\times \times$ & 7 \\
\hline Mustela erminea & & & & & & & & & & & & $x$ & & & & & & & & & & 1 \\
\hline Mustela nivalis & & & & & & & & & & & & $x$ & & $x$ & $x$ & & & & & & & 4 \\
\hline Mustela putorius & & & & $x$ & & & & & & & & & & $x$ & & & & & & & & 2 \\
\hline Meles meles & & & & $x$ & & & & & $x$ & & $x$ & & & $x$ & & $\times \quad x$ & & & & & $\times \quad \times$ & 8 \\
\hline Gulo gulo & & & & & & & & & & & & & & & & & & & & $x$ & & 2 \\
\hline Felis silvestris & & & & $x$ & & & & & & & & $x$ & & $x$ & & & & & $x$ & $x$ & $\times \quad \times$ & 7 \\
\hline Lynx lynx & & & & $x$ & & & & & & & & & & $x$ & & $x$ & & & & & & 4 \\
\hline Panthera spelaea & & & & & & & & & $x$ & & & & & & & & & & & $x$ & & 2 \\
\hline Crocuta crocuta & $\times$ & $x$ & & $x$ & & $x$ & & & & & & & & & & & & & & & & 4 \\
\hline Total & 129 & 9 & 7 & 136 & 2 & 5 & 6 & 2 & 113 & 9 & 104 & 106 & & 169 & 4 & 107 & & 4 & 9 & 135 & 1217 & \\
\hline
\end{tabular}


TABLE 7. - Database and turnover index for large mammal species. Abbreviations: FO, number of first occurrences; LO, number of last occurrences. Turnover Indexes formulas: $\mathrm{TI},=\% \mathrm{FO}+\% \mathrm{LO} / 2$; running mean formulas: rm, = N-(FO+LO/2); percentage of FO formulas: $\% \mathrm{FO},=\mathrm{FO} /$ Running mean ${ }^{\star} 100$; percentage of LO formulas: \%LO, = LO/running mean*100.

\begin{tabular}{|c|c|c|c|c|c|c|c|}
\hline & $\begin{array}{c}\text { No. } \\
\text { species }\end{array}$ & FO & LO & $\begin{array}{c}\text { Running } \\
\text { mean }\end{array}$ & $\% \mathrm{FO}$ & \%LO & $\begin{array}{c}\text { Turnover } \\
\text { index }\end{array}$ \\
\hline \multicolumn{8}{|l|}{ Italy } \\
\hline Holocene/OIS2 & 26 & 0 & 7 & 22.5 & 0 & 31.11 & 15.55 \\
\hline OIS2/Ingarano & 31 & 0 & 5 & 28.5 & 0 & 17.54 & 8.77 \\
\hline Ingarano/Melpignano & 33 & 3 & 3 & 30 & 10 & 10 & 10 \\
\hline Melpignano/Vitinia & 36 & 2 & 5 & 32.5 & 6.15 & 15.38 & 10.76 \\
\hline Vitinia/Torre in Pietra & 27 & 5 & 2 & 23.5 & 21.27 & 8.51 & 14.89 \\
\hline Torre in Pietra/Fontana Ranuccio & 29 & 4 & 7 & 23.5 & 17.02 & 29.78 & 23.4 \\
\hline Fontana Ranuccio/Isernia & 34 & 5 & 9 & 27 & 18.51 & 33.33 & 25.92 \\
\hline Isernia/Ponte Galeria & 31 & 10 & 2 & 25 & 40 & 8 & 24 \\
\hline Ponte Galeria/Slivia & 18 & 4 & 0 & 16 & 25 & 0 & 12.5 \\
\hline Slivia/Colle Curti & 16 & 2 & 3 & 13.5 & 14.81 & 22.22 & 18.51 \\
\hline Ponte Galeria/Colle Curti & 27 & 11 & 6 & 18.5 & 59.46 & 32.43 & 45.94 \\
\hline Colle Curti/Pirro & 22 & 2 & 6 & 18 & 11.11 & 33.33 & 22.22 \\
\hline Pirro/Farneta & 29 & 5 & 9 & 22 & 22.72 & 40.9 & 31.81 \\
\hline Farneta/Tasso & 32 & 6 & 8 & 25 & 24 & 32 & 28 \\
\hline Tasso/Olivola & 31 & 10 & 5 & 23.5 & 42.53 & 21.27 & 31.9 \\
\hline Olivola/Costa S. Giacomo & 26 & 6 & 6 & 20 & 30 & 30 & 30 \\
\hline Costa S. Giacomo/Montopoli & 27 & 10 & 9 & 17.5 & 57.14 & 51.42 & 54.28 \\
\hline Montopoli/Triversa & 24 & 8 & 5 & 17.5 & 45.71 & 28.57 & 37.14 \\
\hline \multicolumn{8}{|l|}{ Central Italy } \\
\hline Holocene/OIS2 & 24 & 0 & 7 & 20.5 & 0 & 34.14 & 17.07 \\
\hline OIS2/Ingarano & 29 & 1 & 5 & 26 & 3.84 & 19.23 & 11.53 \\
\hline Ingarano/Melpignano & 33 & 4 & 5 & 28.5 & 14.03 & 17.54 & 15.78 \\
\hline Melpignano/Vitinia & 34 & 8 & 5 & 27.5 & 29.09 & 18.18 & 23.63 \\
\hline Vitinia/Torre in Pietra & 29 & 7 & 3 & 24 & 29.16 & 12.5 & 20.83 \\
\hline Torre in Pietra/Fontana Ranuccio & 26 & 8 & 5 & 19.5 & 41.02 & 25.64 & 33.33 \\
\hline Fontana Ranuccio/Isernia & 29 & 4 & 11 & 21.5 & 18.6 & 51.16 & 34.88 \\
\hline Isernia/Ponte Galeria & 27 & 12 & 2 & 20 & 60 & 10 & 35 \\
\hline Ponte Galeria/Colle Curti & 17 & 8 & 2 & 12 & 66.66 & 16.66 & 41.66 \\
\hline Colle Curti/Pirro & 10 & 3 & 1 & 8 & 37.5 & 12.5 & 25 \\
\hline Pirro/Farneta & 18 & 1 & 11 & 12 & 8.33 & 91.66 & 50 \\
\hline Farneta/Tasso & 28 & 5 & 11 & 20 & 25 & 55 & 40 \\
\hline Tasso/Olivola & 28 & 5 & 5 & 23 & 21.74 & 21.74 & 21.74 \\
\hline Olivola/Costa S. Giacomo & 34 & 15 & 11 & 21 & 71.42 & 52.38 & 61.9 \\
\hline Costa S. Giacomo/Montopoli & 25 & 11 & 5 & 17 & 64.7 & 29.41 & 47.05 \\
\hline Montopoli/Triversa & 15 & 12 & 2 & 8 & 150 & 25 & 87.5 \\
\hline
\end{tabular}

